2011s-19

\title{
Assessment of International Economic Policy Models and Measures: Lessons for Canada
}

Marcel Boyer, Anne Catherine Faye

\begin{tabular}{c}
\hline Série Scientifique \\
Scientific Series
\end{tabular}

Montréal

Février 2011

(C) 2011 Marcel Boyer, Anne Catherine Faye. Tous droits réservés. All rights reserved. Reproduction partielle permise avec citation du document source, incluant la notice (C).

Short sections may be quoted without explicit permission, if full credit, including (C) notice, is given to the source.
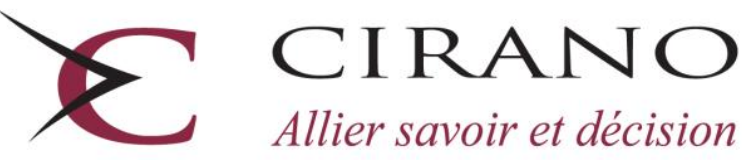

Allier savoir et décision

Centre interuniversitaire de recherche en analyse des organisations 


\section{CIRANO}

Le CIRANO est un organisme sans but lucratif constitué en vertu de la Loi des compagnies du Québec. Le financement de son infrastructure et de ses activités de recherche provient des cotisations de ses organisations-membres, d'une subvention d'infrastructure du Ministère du Développement économique et régional et de la Recherche, de même que des subventions et mandats obtenus par ses équipes de recherche.

CIRANO is a private non-profit organization incorporated under the Québec Companies Act. Its infrastructure and research activities are funded through fees paid by member organizations, an infrastructure grant from the Ministère du Développement économique et régional et de la Recherche, and grants and research mandates obtained by its research teams.

\section{Les partenaires du CIRANO}

Partenaire majeur

Ministère du Développement économique, de l'Innovation et de l'Exportation

\section{Partenaires corporatifs}

Banque de développement du Canada

Banque du Canada

Banque Laurentienne du Canada

Banque Nationale du Canada

Banque Royale du Canada

Banque Scotia

Bell Canada

BMO Groupe financier

Caisse de dépôt et placement du Québec

Fédération des caisses Desjardins du Québec

Financière Sun Life, Québec

Gaz Métro

Hydro-Québec

Industrie Canada

Investissements PSP

Ministère des Finances du Québec

Power Corporation du Canada

Raymond Chabot Grant Thornton

Rio Tinto

State Street Global Advisors

Transat A.T.

Ville de Montréal

\section{Partenaires universitaires}

École Polytechnique de Montréal

HEC Montréal

McGill University

Université Concordia

Université de Montréal

Université de Sherbrooke

Université du Québec

Université du Québec à Montréal

Université Laval

Le CIRANO collabore avec de nombreux centres et chaires de recherche universitaires dont on peut consulter la liste sur son site web.

Les cahiers de la série scientifique (CS) visent à rendre accessibles des résultats de recherche effectuée au CIRANO afin de susciter échanges et commentaires. Ces cahiers sont écrits dans le style des publications scientifiques. Les idées et les opinions émises sont sous l'unique responsabilité des auteurs et ne représentent pas nécessairement les positions du CIRANO ou de ses partenaires.

This paper presents research carried out at CIRANO and aims at encouraging discussion and comment. The observations and viewpoints expressed are the sole responsibility of the authors. They do not necessarily represent positions of CIRANO or its partners. 


\title{
Assessment of International Economic Policy Models and Measures: Lessons for Canada
}

\author{
Marcel Boyer ${ }^{*}$, Anne Catherine Faye ${ }^{*}$
}

\begin{abstract}
Résumé / Abstract
Nous analysons quatre systèmes socio-économiques qui représentent différents groupes de pays. Ces modèles socio-économiques incluant le modèle nordique, l'anglo-saxon, le continental et le méditerranéen sont décrits à travers quelques politiques publiques instaurées dans certains pays. En particulier, nous étudions les réformes de la Suède dans les secteurs de l'éducation et du marché du travail, de la France dans les télécommunications et la santé, du Royaume-Uni dans l'attribution des contrats dans le secteur public, et du Chili pour son expansion économique liée au commerce. Suite à cette analyse, nous identifions des leçons importantes et quelques avenues de réformes pour le Canada.
\end{abstract}

Mots clés : Modèle socio-économique nordique, modèle socio-économique anglosaxon, modèle socio-économique continental, modèle socio-économique méditerranéen, réformes économiques, Canada.

We consider a typology of four social and economic policy models each pertaining to different groups of countries. These four policy systems namely the Nordic model, the Anglo-Saxon model, the Continental model, and the Mediterranean model, are described individually and in terms of selected public policies. In particular, we review the Swedish economic experience in promoting flexible labour markets and reforming its education sector, the French regulatory reforms in telecommunications and health care sectors, the competitive compulsory tendering and best value reforms in the United Kingdom, and the recent economic growth led by trade in Chile. Finally, we draw important lessons for reforms in Canada.

Keywords: Nordic economic model, Anglo-Saxon economic model, continental economic model, mediterranean economic model, economic reforms, Canada.

\footnotetext{
* Bell Canada Emeritus Professor of Industrial Economics, Université de Montréal, Research Associate, Department of Economics, École Polytechnique de Paris, University Affiliate, Analysis Group, Inc., Fellow of CIRANO, CIREQ and C.D. Howe Institute.

${ }^{\dagger}$ Economist, Analysis Group, Inc.
} 


\section{TABLE OF CONTENTS}

$\begin{array}{ll}\text { TABLE OF CONTENTS } & 1\end{array}$

$\begin{array}{ll}\text { INTRODUCTION } & 2\end{array}$

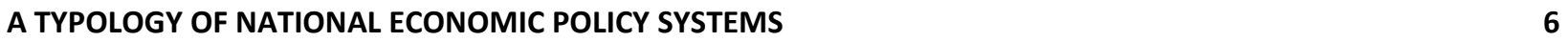

The Nordic Model $\quad 6$

$\begin{array}{ll}\text { The Anglo-Saxon Model } & 8\end{array}$

$\begin{array}{ll}\text { The Continental Model } & 10\end{array}$

The Mediterranean Model 11

Wrap up 13

THE SWEDISH ECONOMIC EXPERIENCE: PROMOTING LABOUR MARKETS FLEXIBILITY AND REFORMING THE EDUCATION SECTOR $\quad 14$

PROMOTING LABOUR MARKET FLEXIBILITY

Lessons for Canada $\quad 17$

REFORMING THE EDUCATION SECTOR 20

Lessons for Canada $\quad 23$

FRENCH REGULATORY REFORMS IN TELECOMMUNICATIONS AND HEALTH CARE 27

$\begin{array}{ll}\text { THE TELECOMMUNICATIONS SECTOR } & 27\end{array}$

Lessons for Canada $\quad 31$

HEALTH CARE

$\begin{array}{ll}\text { Lessons for Canada } & 40\end{array}$

COMPETITIVE COMPULSORY TENDERING AND BEST VALUE IN THE UNITED KINGDOM 44

COMPETITIVE COMPULSORY TENDERING

BEST VALUE $\quad 46$

$\begin{array}{ll}\text { Lessons for Canada } & 49\end{array}$

CHILE'S TRADE-LED GROWTH

Lessons for Canada $\quad 59$

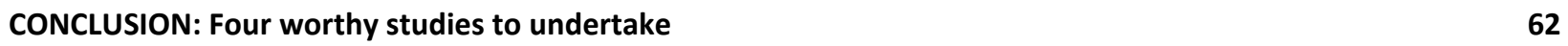

$\begin{array}{lr}\text { REFERENCES } & \mathbf{7 0}\end{array}$ 


\section{INTRODUCTION}

The recent economic recession has brought to the forefront numerous discussions regarding the resilience of different levels or scopes of government involvement in the economy. It is believed in many circles that countries or regions where the government's "share" of the economy is large have been more resilient. ${ }^{1}$ These and other related issues will be debated for some time before more rigorous academic research is produced to identify the causes of relative resilience in the specific case of the recent economic recession.

An important debate on the ways and means by which the State's actions and interventions take place will or should be at the forefront. The role, scale and scope of the State as provider of last resort, as planner of design activities and programmes ${ }^{2}$, and as regulator and guarantor of the legal framework and integrity of markets as an exchange mechanism will keep being discussed both in normal and abnormal (crisis) times. In a sense, it is important to distinguish between the objectives pursued and the ways and means used to meet the challenges raised by the role, scale and scope of the State in modern economies. This distinction evolves essentially on the role of the State in ensuring the proper level of planning and coordination in design activities and programmes, and the ways and means used to achieve or fulfill this role.

In many cases, the role played by the State as provider and planner blur the perception of the scale and scope of its interventions. For instance, if a government acts as planner of the transportation system (highways, trains, airports), but enters into long term public private partnership contracts with the private sector to implement the plan, its role becomes quite different from a government that enters into short term building contracts only to realize the desired infrastructure. Similarly, if a government acts as planner of a universal health care system, but implements it with a strong participation by the private sector rather than through governmental organizations alone, then again its role cannot be characterized as similar in both cases.

\footnotetext{
${ }^{1}$ Among the numerous references to this "theory", one may cite The Economist, "Vive la difference", May $7^{\text {th }} 2009$.

${ }^{2}$ Design activities and programmes refer to those activities and programmes where the technical or technological coordination of the different actors is of utmost importance. On may mention among other examples the determination of network (railways, telecoms, energy transportation through electric grids and pipelines, etc.) access and inter-access rules and conditions.
}

Page $\mid 2$ 
In many countries, the size and scope of the government is recognized as one of the important causes of business cycles. For instance, in the US, the extensive but ill-fated interventions of the US government in mortgage markets, mainly through Fannie Mae and Freddie Mac has been cited among the different causes of the recent global recession as well as the rapid development of advanced and potentially fruitful, but at times poorly understood, financial products (complex derivatives such as $\mathrm{ABS}$ and $\mathrm{ABCP}^{3}$ ); the relatively lax supervision of financial institutions by regulatory bodies and the relatively lax monitoring - a common agency problem - by financial institutions of their investments in complex financial products; the ill conceived incentive remuneration schemes in the financial sector; and in the end the lost confidence in the stability of the financial system.

At a more fundamental level, most current debates on social, economic and political issues, in particular comparing different "national economic systems" characterized by more or less government interventions, stem not from conflicts between left and right or (market) socialism and neo-liberalism, but rather from a confusion between ends and objectives on the one hand and ways and means on the other. People may disagree on the macro-social and economic goals and objectives that their society should pursue. They may also disagree about the relative efforts that should be exerted towards wealth creation and wealth redistribution and the efficiency of different ways and means that could be implemented to achieve common goals and objectives. But when there is confusion between goals and objectives on the one hand and ways and means on the other, the debate becomes in good part spurious. Thus, while the debates about goals and objectives are societal by nature, the debates about ways and means should rather be technical.

A goal must be socially shared, that is a majority of citizens must agree to pursue it, or at least have a way to build a consensus, for instance through an open and transparent electoral process. Once the goal is set, it must be reached using ways and means. The discussion then becomes more technical: What resources and technologies are available? How efficiently can they allow a country to reach its goal? How much do they cost? The discussion on ways and means deals essentially with relative efficiency and relative costs. Achieving a consensus on goals and objectives requires an efficient political competitive process with candidates competing to obtain the electoral support (basically democratic election rules and institutions), while achieving a

\footnotetext{
${ }^{3}$ ABS: Asset Backed Securities; ABCP: Asset Backed Commercial Paper.

Page |3
} 
consensus on ways and means requires an efficient economic competitive process (basically competitive markets, processes, and prices). ${ }^{4}$

In the following sections, we discuss important national economic models and programs implemented in different countries over the last 25 years or so. We show how a simplistic representation of important features of national economic models, characteristics that one can find too often in the press, may indeed blur and bias our understanding of factors explaining the relative efficiency, effectiveness and resiliency of these national economic models. In doing so, we identify lessons for the Canadian public policy agenda.

More specifically:

1. We first present a typology of national social and economic systems with four broadly defined types: the Nordic, Anglo-Saxon, Continental Europe, and Mediterranean Europe models, each with its strengths and weaknesses. We then proceed in the following sections with specific sets of reforms in the first three models, which are likely to strike a sensitive chord in the context of the Canadian social and economic system.

2. We describe the important role of French competition bodies in the telecommunications markets; we also evaluate the presence of the private for-profit sector in the French health care system. These two policy compacts are of the utmost importance in the Canadian context with the federal and provincial governments being closely intertwined in finding solutions to different problems and challenges.

3. We analyze economic incentives used in Sweden to boost participation in the labour market and to improve educational attainment through some form of privatization-like education reforms. Again these two policy compact pose significant challenges for the Canadian social and economic system.

4. We review the United Kingdom past experience with the provision and delivery of local public services using the policies of Competitive Compulsory Tendering and Best Value aimed at encouraging the participation of non-state entities. The Canadian delivery

\footnotetext{
${ }^{4}$ See for a more elaborate discussion Marcel Boyer, Manifesto for a Competitive Social Democracy, CIRANO Monograph 2009.

Page $\mid 4$
} 
system for public and social goods and services, both at the Federal and Provincial level, is entering a difficult period as the institutions involved are getting bogged down with organizational inefficiencies and as productivity gains appear more difficult to achieve. Hence the interest of looking at the U.K. experience.

5. We review an additional social and economic system, namely that of Chile. Its economic success was significantly driven by trade openness, privatization of state-owned enterprises and price liberalizing policies. These economic strategies have placed the country ahead of its Latin American counterparts by many measures. A significant lesson can be drawn from Chile's experience: liberalizing prices toward intense competitiondetermined prices can generate enormous benefits in terms of economic growth and standards of living.

Some of the lessons we identify here may pose constitutional problems given the separation of powers between the federal and provincial Governments. However, such constitutional challenges need not prevent or interfere with discussions of a common policy agenda in some sectors. Indeed, all economic sectors, including the public and social goods and services sectors, fall, although in different ways, under both the jurisdiction of the federal government and that of the provincial government. 


\section{A TYPOLOGY OF NATIONAL ECONOMIC POLICY SYSTEMS}

It may be useful to consider a typology of four models to distinguish between national social and economic policy systems. These models apply to different groups of countries.

- The Nordic Model regroups Denmark, Finland, Sweden, and the Netherlands.

- The Anglo-Saxon Model regroups Ireland and the United Kingdom (UK) in Europe, as well as the U.S., Australia, and New Zealand.

- The Continental Model regroups France and Germany, as well as Austria, Belgium, and Luxembourg.

- The Mediterranean Model regroups countries such as Portugal, Italy, Greece, and Spain (The so-called PIGS countries).

In addition to differences between these four aggregate models, other dissimilarities clearly exist among countries within each model. However for simplicity purposes, the following sections will overlook individual countries and rather compare the performance of these models in terms of selected social and economic policies.

\section{The Nordic Model}

Nordic economies are characterized by a combination of generous state provision and high levels of taxation. Universal social protection as a pillar value is reflected in the presence of a large public sector in these countries. During the current decade, the Nordic model has been praised as a great means to achieve a so-difficult equilibrium between market-oriented policies and the pursuit of substantial welfare strategies. Heavy restructuring in the wake of imbalances generating high inflation, high unemployment, and huge budget deficits in the 1980s and 1990s has resulted in economic revival translating into enviable positions among the richest economies.

These changes were fundamental in bringing increased competition in every major sector while carrying little changes to the welfare model. Public expenditures are still used to finance largescale services and transfers from free day care, education, and health care to generous benefits in housing, unemployment, and other social subsidies, almost universally. Using taxes and 
transfers, Nordic countries have been able to reach a 42 per cent reduction of income inequality and poverty, i.e. the highest level of redistribution among countries with other social models. ${ }^{5}$ Nordic citizens are also more likely to avoid poverty due to the extent of this redistribution policy but also as a result of higher education attainment. ${ }^{6}$

Although active intervention on labour markets and strong unions ensure the provision of generous unemployment benefits, workers' acceptance of high taxes, which permits a strong social safety net, has allowed an easing of employment protection legislation and of relations between workers and employers. Employment rates have been higher in Nordic countries than in other European countries. ${ }^{7}$

At the same time, Nordic economies grew at a faster pace than countries in the European Union (EU) area - albeit slower than the American economy - between 1993 and 2005. ${ }^{8}$ Over the years, Nordic countries have consistently performed better than their counterparts by many measures including the Human Development Index, the Growth Competitiveness Index, and the Quality of Life Index. ${ }^{9}$ More importantly, Nordic countries are ranked as the least corrupt in the world by Transparency International leading in part to the wide acceptance of high taxation levels among citizens.

On the other side, there is no mistake: the cost of such universal provision of welfare is very important. Taxes in Nordic countries represent nearly 50\% of gross domestic product (GDP), higher than in any other developed country. ${ }^{10}$ Critics of the Nordic model also stem from the high tax burden imposed on the country's companies leading them to operate from foreign locations. Notable examples include IKEA or Skype, companies created in Sweden but run from abroad. The success of the Nordic model is also believed to be linked to these countries' small

\footnotetext{
${ }^{5}$ Boeri, T. (2002), 'Let Social Policy Models Compete and Europe Will Win', Paper presented at a conference hosted by the Kennedy School of Government, Harvard University, 11-12 April.

${ }^{6}$ Sapir, Andre, 'Globalization and the Reform of European Social Models', Journal of Common Market Studies, Vol. 44, No. 2, pp. 369-390, June 2006.

${ }_{8}^{7}$ OECD Data, various years.

8 Growth in the Nordic business sector, Nordic Council of Ministers, Copenhagen 2007, available at: http://www.norden.org/sv/publikationer/publikationer/2008-503/at_download/publicationfile

${ }^{9}$ The HDI is an annual measure developed by the United Nations Development Program; the GCI is drawn up by the World Economic Forum; the QLI is developed by the Economist Intelligence Unit.

${ }^{10}$ Thomas Fuller and Ivar Ekman, The Envy of Europe, The New York Times, September 2005.
} 
and homogenous populations which create a greater sense of national collectiveness but render difficult the development of generous and permissive immigration and integration policies.

The Nordic social model has proven to deliver efficiency as it generates relatively high employment rates and equity as it keeps the risk of poverty relatively low. ${ }^{11}$ The current global downturn is putting under test the Nordic model as the region's economy deeply contracted, mirroring the worst GDP results seen in decades. In the context of rapid changes due to globalization, technology, and population ageing, the Nordic experience may offer valuable lessons on reforms during challenging economic times.

\section{The Anglo-Saxon Model}

The Anglo-Saxon Model is often described as a capitalist model with liberalization and deregulation-driven policies. In economic terms, this model encourages free market capitalism and competition between individuals, firms and organizations. Government intervention is limited and markets are relied upon to efficiently allocate resources in the economy. The provision of social transfers, relatively lower in the Anglo-Saxon model than in other social models, is generally means-tested and targeted to low-income populations.

Labour markets are substantially decentralized, resulting in weak labour unions as working conditions are mainly determined at the firm level. In fact, workers in the Anglo-Saxon model are to a larger extent less protected by employment protection legislation, but as much protected against labour market risk than workers in the Continental and Nordic countries. ${ }^{12}$ High employment rates in Anglo-Saxon countries are largely explained by low-wage service jobs. ${ }^{13}$

Compared to countries with other social models, Anglo-Saxon countries are not performing as well in reducing income inequality and the incidence rate of poverty. UK and Ireland are stout champions of Anglo-Saxon liberalism in Europe, although Ireland has experienced greater policy

\footnotetext{
${ }^{11}$ Sapir, Andre, 'Globalization and the Reform of European Social Models', Journal of Common Market Studies, Vol. 44, No. 2, pp. 369-390, June 2006.

${ }^{12}$ Idem

${ }^{13}$ Alois Guger, Thomas Leoni, Ewald Walterskirchen, European Socio-Economic Models: Experiences and Reform Perspectives, Annex 3 - EUROFRAME-EFN Autumn 2007 Report.

Page $\mid 8$
} 
interventions reflecting the country's transition from a low-income to one of the best performing European economies before the recent recession. Until the 2008 global crisis, UK has experienced steady economic growth while Ireland outperformed many other European countries by reaping some of the greatest benefits of globalization as a small and open economy.

The U.S. has experienced a very high job creation level since the early 80s with no less than 45 million net new jobs created between 1981 and 2008. ${ }^{14}$ For the 65 quarters from the third quarter of 1992 to the third quarter of 2008, private U.S. companies have created an average of 357000 net new jobs per quarter. In gross terms, these companies have actually created an average of 7 863000 new jobs per quarter, including 6217000 or $79 \%$ in existing facilities and 1646000 or $21 \%$ following the opening of new establishments, but have also lost an average of 7506000 jobs per quarter, including 5983000 or $80 \%$ in existing facilities and 1523000 or 20\% due to business closures. Thus each new net job created during those 65 quarters resulted from an average of 21 jobs created and 20 jobs lost. Similarly, over the same 65 quarters, the U.S. economy has created no less than 18000 new establishments on average per quarter. In gross terms, private U.S. companies have opened an average of 337000 new establishments, representing an average of 1646000 new jobs, and closed an average of 320000 establishments per quarter, representing an average of 1523000 jobs lost. Hence, each net new establishment resulted from an average of 19 openings and 18 closures, with an average of 133000 net new jobs created per quarter. This is a striking example of aggressive creative destruction at work, an important resulting characteristic of the Anglo-Saxon Model.

Overall, Anglo-Saxon countries face a trade-off between on the one hand efficiency which their model delivers through aggressive creative destruction, strong incentives for labour market participation and therefore high employment rates, and on the other hand equity, at least some notion of equity, which the model appears to be failing to provide at relatively high levels. ${ }^{15}$

The global downturn has brought a backlash against free market approaches of which the AngloSaxon Model is the typical representative and proponent and sparked much criticism from many

\footnotetext{
${ }^{14}$ See Marcel Boyer, «La performance et le développement économiques du Québec: les 12 travaux d'Hercule », CIRANO, novembre 2009. See also Marcel Boyer, «The Economic Crisis and Employment Dynamics: The Creative Destruction at Work », Montreal Economic Institute, November 2009.

${ }^{15}$ Sapir, Andre, 'Globalization and the Reform of European Social Models', Journal of Common Market Studies, Vol. 44, No. 2, pp. 369-390, June 2006. 
experts on self-regulation, which too often implied little to no regulation. Market failures such as the presence of bubbles in asset pricing or distortions in workers' compensation have weakened beliefs in the efficiency markets. Before the current crisis, financial globalization had gained substantial ground and market-based policies were steadily promoted in every sector. Strong growth further encouraged deeper and more aggressive deregulation. Although few believe that the current situation marks the end of free market economics, many observers express and support the need of more adequate supervision and regulation. Furthermore, the crisis has given rise to an extensive and intensive search for viable alternatives to the Anglo-Saxon Model, including the praise of features defining the Continental Model to which we now turn to.

\section{The Continental Model}

The Continental Model is routinely depicted as a system featuring significant government intervention in the economy, generous unemployment benefits, publicly provided pensions, and universal comprehensive health care benefits. In addition, the model involves close, even heavy regulation over labour markets and all major industrial sectors. The Continental Model has long suffered from its (at least since the early nineties, therefore much before the current crisis) image of sluggish growth rates and high unemployment levels relative to those observed in AngloSaxon and Nordic countries, suggesting a failure to fulfill both economic performance and social justice. These conditions triggered numerous debates over the sustainability of the Continental Model, exacerbated by the huge public deficits and significant social systems drains on public finances, the additional burden of population ageing on welfare systems, and the needs to find acceptable ways to adjust to globalization and increased international competition.

The Continental Model seconds the Nordic Model in terms of income inequality and poverty incidence reduction. However, although it provides similarly generous unemployment benefits, the Continental Model provides for stricter employment protection legislation. Social consensus on the principles of social equity has driven up welfare expenditures and employment protection laws and programmes to relatively high levels at the cost of long-term economic viability. The rigidity of labour markets is alleged to be contributing to the high unemployment rates while 'biased' employment protection limits labour market participation of groups such as workers 
aged 15-24 and women. Many have pointed out at levels of public debt as alarming signs of the unsustainability of the Continental Model: the welfare state systems have succeeded in reducing inequality at the cost of high inefficiency. ${ }^{16}$ The need for change has been consistently pressed by policymakers and international bodies, but resistance against scaled-back social benefits and lower employment protection regulations in order to encourage market incentives has impeded reform agendas.

France and Germany represent major economies among the Continental countries. Policymaking in these two countries has been shifting towards more reforms in crucial areas. More importantly, social partners, unions, and employers are increasingly taking initiatives to promote reforms rather than simply reacting to government proposals by support or opposition. For instance, legislation to further liberalize the 35-hour week laws in France has been put in place through the initiative and support from employer groups. In Germany, the Merkel government is working with policy designs and implementations using a less hands-on style than before.

While Continental countries have been hit by the global economic meltdown, especially heavyexporter Germany, these challenging economic times have also exposed its relative strengths and resilience. Citizens of Continental economies were better protected against austere economic conditions that call for a sudden rise in unemployment and/or a significant drop in income. Latest data show France and Germany leading the way to economic recovery sooner than expected. As a result, Anglo-Saxon countries are actively pursuing a so-called "interventionist" group of strategies following those of continental countries, in particular in Britain where the government is ushering in new financial rules and higher taxes and in America where the president has suggested copying some social and economic policies from France. ${ }^{17}$

\section{The Mediterranean Model}

The last major social and economic policy model may be called the Mediterranean Model. This model portrays a social welfare system with strict employment protection legislation and a low

\footnotetext{
${ }^{16}$ Sapir, Andre, 'Globalization and the Reform of European Social Models', Journal of Common Market Studies, Vol. 44, No. 2, pp. 369-390, June 2006.

${ }^{17}$ The Economist, A New Pecking Order, May $7^{\text {th }} 2009$. 
provision of unemployment benefits. Early retirement schemes prevent or at least discourage longer participation in the labour market while contributing to low employment levels relative to countries with other social models. In addition, the formal economy is characterized by rigidity and high compression in the wage structure. Low coverage against unemployment also leads to relatively high levels of poverty. The model features a large public sector and substantial public or social expenditures largely directed towards pension systems.

The extent of reduction of income inequality and poverty incidence using taxes, transfers, and social subsidies is lower in Mediterranean countries compared to other social and economic policy model countries. The share of persons with an income below the risk-of-poverty threshold, set at $60 \%$ of the national median disposable income, is larger in Mediterranean countries than in Nordic countries, Continental countries and Anglo-Saxon countries. ${ }^{18}$ Furthermore, workers in Mediterranean countries are less rewarded for participating in labour markets and therefore employment rates are higher than in countries with different social and economic models. The Mediterranean Model puts public finances under severe constraints and generally fails to provide either efficiency or equity.

The sustainability of Mediterranean economies is a real concern in the Euro area. A cyclical economic boom in Greece, Portugal, and Spain led to a substantial loss of competitiveness. In particular, rapid wage inflation put local companies at a disadvantage on international markets, current account deficits significantly increased, and unemployment kept rising. ${ }^{19}$ Although Italy escaped such a similar dire path, Mediterranean countries experienced during the current decade the slowest economic growth among European countries. While reforms towards greater productivity are urgently needed, tougher labour policies or wage growth restrictions are not available options, given the strong constituents' opposition. Mediterranean countries are facing further challenges with globalization and their social model has proven struggling behind other systems.

\footnotetext{
${ }^{18}$ Sapir, Andre, 'Globalization and the Reform of European Social Models', Journal of Common Market Studies, Vol. 44, No. 2, pp. 369-390, June 2006.

${ }^{19}$ The Economist, A Decade in the Sun, June $5^{\text {th }} 2008$. 


\section{Wrap up}

The Nordic model concurrently provides efficiency and equity at higher levels than any other social model. This model together with the Anglo-Saxon system is deemed sustainable. The Continental and the Mediterranean models are under stress to actively put in place major reforms to tackle inefficiencies. These struggling countries represent a combined important share of the European Union which makes changes more pressing.

The different social models presented above have important dissimilarities but they are all in constant change. Efforts to revitalize labour markets and reform social policies should be continuous in order to improve the state of national economies. Globalization and technological change offer full opportunity to economies capable of maintaining their competitive edge in the global economy. 


\section{THE SWEDISH ECONOMIC EXPERIENCE: PROMOTING LABOUR MARKETS FLEXIBILITY AND REFORMING THE EDUCATION SECTOR}

Sweden's economic and social system is either intensively praised or vigorously criticized. The Swedish model is often depicted as a compromise between a social welfare-based state and liberal attitudes. Throughout the years, the model has changed considerably.

From the late $19^{\text {th }}$ century to the late $60 \mathrm{~s}$, Sweden has transformed from a rural poor country into one of the most thriving economies of that era in terms of GDP and productivity. During this period, market-driven policies such as the removal of trade barriers, boosted production and the development of a vibrant export sector. A second era started with the social-democratic government ruling, starting in the late 60s. Although the free-trade regime was strengthened due to increasing global trade liberalization, the welfare state developed tremendously with generous government programs. Social welfare programs relied on high tax rates while redistribution goals led to substantial government intervention in all economic sectors particularly in the labour market. Labour unions were given extended rights and power. ${ }^{20}$ High taxation and excessive government intervention created economic disincentives with deterrent impact on job creation and entrepreneurship. To support welfare policies, public spending grew rapidly from $31 \%$ to $60 \%$ of GDP between 1960 and 1980. GDP per capita declined considerably compared to OECD countries, from the fourth most performing economy in 1970 to the $16^{\text {th }}$ rank in $1995 .^{21}$

In the early 1990s, Sweden experienced a severe contraction during the global economic crisis. The Swedish economy was in decline by many measures with unemployment rate at $10.3 \%$, public spending at $72.4 \%$ of GDP, and budget deficits at $14.4 \%$ of GDP in $1993 .{ }^{22}$ This alarming situation gave rise to a series of reforms with broad public and political support. This period was marked by the implementation of deregulation and privatization policies.

\footnotetext{
${ }^{20}$ Olle Krantz, Economic Growth and Economic Policy in Sweden in the 20th Century: A Comparative Perspective, The Ratio Institute, March 19, 2004. Angus Maddison, The World Economy: Historical Statistics, OECD, 2003.

${ }^{21}$ Labrie, Y, How to Explain the Success of the Swedish Model, Montreal Economic Institute, Economic Note - July 2007.

${ }^{22}$ Idem

Page $\mid 14$
} 


\section{PROMOTING LABOUR MARKET FLEXIBILITY}

Agreements with labour market organizations strengthened the decentralization of wage-settings. By the mid-90s, pay structures were decided at the local level although guarantees of minimum wages remained embedded in contracts. At the same time, legislation regarding temporary work was relaxed. Although this decentralization increased the wage dispersion among employees, average real wages grew by $43 \%$ for white-collar workers and $22 \%$ for blue-collar workers between 1995 and $2005 .^{23}$

Various incentives to work were also introduced to curtail unemployment levels. For instance, sickness compensation was reduced and built on the length of insurance and supplementary insurance. Employers were made responsible for the first two weeks of sickness for less contribution to social security. ${ }^{24}$ Training programs with a focus of employability and adult education were designed and attracted high levels of participation. Between 1997 and 2000, the Adult Education Initiative, an important adult education program intended for low-skilled workers, saw the participation of more than $10 \%$ of the labour force. ${ }^{25}$ Other initiatives such as employment subsidies and trainee replacement were administered to improve individual employment opportunities.

However, the two components of the Swedish labour market, i.e. a benefit system for the unemployed and active market programs to raise employment opportunities, were likely conflicting in some fronts. Unemployment rates gradually decreased until the end of the 1990s but started rising again after 2000. Sweden has a generous unemployment insurance program in which up to $80 \%$ of the previous wage can be compensated and eligibility to these benefits extended for up to three years. ${ }^{26,27}$ According to the OECD in 2005 Sweden had $14 \%$ of its working-age population claiming sickness and disability benefits more than in any other OECD country. At the same time, the share of sickness absences exceeding six months was more than

\footnotetext{
${ }^{23}$ Davis, S. and Henrekson, M., Economic Performance and Work Activity in Sweden after the Crisis of the Early 1990s, NBER Working Paper No. 12768, December 2006.

${ }^{24}$ Aiginger, Karl, The Swedish Economic Model, WIFO Working Papers, No. 302, October 2007.

25 Albrecht, J., van den Berg, G. and Vroman, S., The Aggregate Labour Market Effects of the Swedish Knowledge Lift Program, Centre for Economic Policy Research CEPR Discussion Paper No. 5927, 2006.

${ }^{26}$ Sianesi, Barbara, Swedish active labour market programmes in the 1990s: Overall effectiveness and differential performance, The Institute for Fiscal Studies, February 2002.

27 The Economist, The Swedish Model, September $7^{\text {th }} 2006$.
} 
$50 \%$ in Sweden, compared to only $10-20 \%$ in other OECD countries. ${ }^{28}$ Moreover, the effective marginal tax wedge was estimated at above $70 \%$ driven by a combination of social contributions, income and consumption taxes. ${ }^{29}$ The McKinsey Global Institute reported that Sweden's "de facto" unemployment rate was between 15 and $17 \% .{ }^{30}$ This report stirred much controversy and criticism on the Sweden economic model. These failures pressed the new Swedish government installed in 2006 to initiate major reforms.

Since 2008, the sickness benefit duration has been capped to six months, disability benefit can no longer be temporary or permanent but only granted for permanent reductions in work capacity, and employers are now subsidized for hiring long-term unemployed and individuals previously on sickness, rehabilitation or disability benefits. In addition, the National Board of Health and Welfare developed guidelines for appropriate periods of sickness absence for the 90 medical conditions that account for approximately three quarters of sickness leaves taken in Sweden. An additional tax credit was also introduced for people who remain in paid work. ${ }^{31}$ The full extent of these reforms remains to be seen as the global recession negatively impacts the labour market with a projected increase in unemployment over the next two years.

In many aspects, Sweden's labour market policies present valuable guidance on how to deal with structural inefficiencies and traditional moral hazard problems. In particular, Sweden's experience with successful programs for low-skilled workers in adult education and the difficult balance between (i) the protection of the unemployed, (ii) the setting of the minimum wage, and (iii) the incentives for work are worth reviewing by other policymakers.

\footnotetext{
${ }^{28}$ OECD Press Release, Sweden's sickness and disability reforms on track but could be improved, says OECD, March $3^{\text {rd }} 2009$.

${ }^{29} \mathrm{~A}$ tax wedge is defined as the difference between before-tax and after-tax wages. OECD, Tax and Growth: What Direction should Sweden Take? Lecture by Angel Gurría, OECD Secretary-General, at Stockholm School of Economics, Stockholm, 22 April 2008.

${ }^{30}$ McKinsey Global Institute, Sweden's Economic Performance: Recent Development, Current Priorities, May 2006. Available at http://www.mckinsey.com/mgi/publications/sweden

To arrive at the 15 to 17 percent "de facto" unemployment rate, McKinsey included "people who don't work, even though they should be able to" in the pool of the unemployed. These groups that McKinsey added to the unemployed included: "latent job candidates", "the under-employed", those "excluded from the labour force with ability to work", and workers on government programs.

${ }^{31}$ Gomes, A. et al. "Sickness, Disability and Work: Breaking the Barriers, Sweden: Will the Recent Reforms Make it?" OECD Data 2009.
} 


\section{LESSONS FOR CANADA}

Formal education is only part of the system by which individuals acquire competencies that allow them to contribute to the best of their potential to social well-being. The other major part pertains to lifelong learning and training programs. Here the fundamental objective is to maintain the employability of workers, of all levels and ages for all trades and professions.

It is impossible to conceive a social project based on cohesion and economic growth without addressing the plague of unemployment and misemployment, a significant waste of society's resources. As such, deregulation of labour markets - for example making it easier for firms to increase and decrease their labour force - is at the heart of the employment debate in OECD countries and elsewhere. ${ }^{32}$

Authorities must seek to address directly and reconcile the seemingly contradictory demand by firms for greater flexibility in managing their labour force and the demand by workers for extensive job security. Higher employment protection tends to reduce layoffs during economic downturns and thus increases job stability. This is likely to favour workers' effort and willingness to acquire specific human capital through in-house training and may have positive implications for aggregate employment and economic performance. However, higher employment protection legislation (EPL) increases labour-cost risk for firms and diminishes their ability to cope with a rapidly changing and volatile socio-economic environment. "Hence, higher employment protection affects hiring decisions in periods of rising demand. Indeed, when deciding whether to hire new workers on permanent contracts, firms take into account the expected costs of possible layoffs in the future. This may make it more difficult for job seekers to find a job, thus favouring long-term unemployment. Stricter employment protection may also be a factor behind the rise in temporary contracts and part-time jobs observed in many OECD countries.",33

"There are several dimensions to the concept of labour market security: stability in employment, the opportunity to find a new job quickly after a spell of unemployment or inactivity, and finally income security for those who are working or are looking for work. Employment protection

\footnotetext{
${ }^{32}$ OECD Observer (September 2004).

${ }^{33}$ Idem

Page | 17
} 
legislation seems to contribute mainly to the first of these dimensions, namely the stability of employment relationships. The other side of the medal is that job protection also tends to prolong the average spell of unemployment, thus contributing to one form of labour market insecurity... [T] here is no evidence that workers feel more secure about their job in countries where they are more protected against layoffs. Strikingly, not only does more stringent employment protection make temporary workers feel less secure, but it seems also to have a similar effect on the very workers that it is meant to protect." ${ }^{34}$ Unemployment allowances may reassure workers, while employment protection legislation may make them anxious. The following chart is a clear illustration of this phenomenon.

\section{Figure 1: No evidence that stringent EPL makes workers more secure about their job ${ }^{35}$}

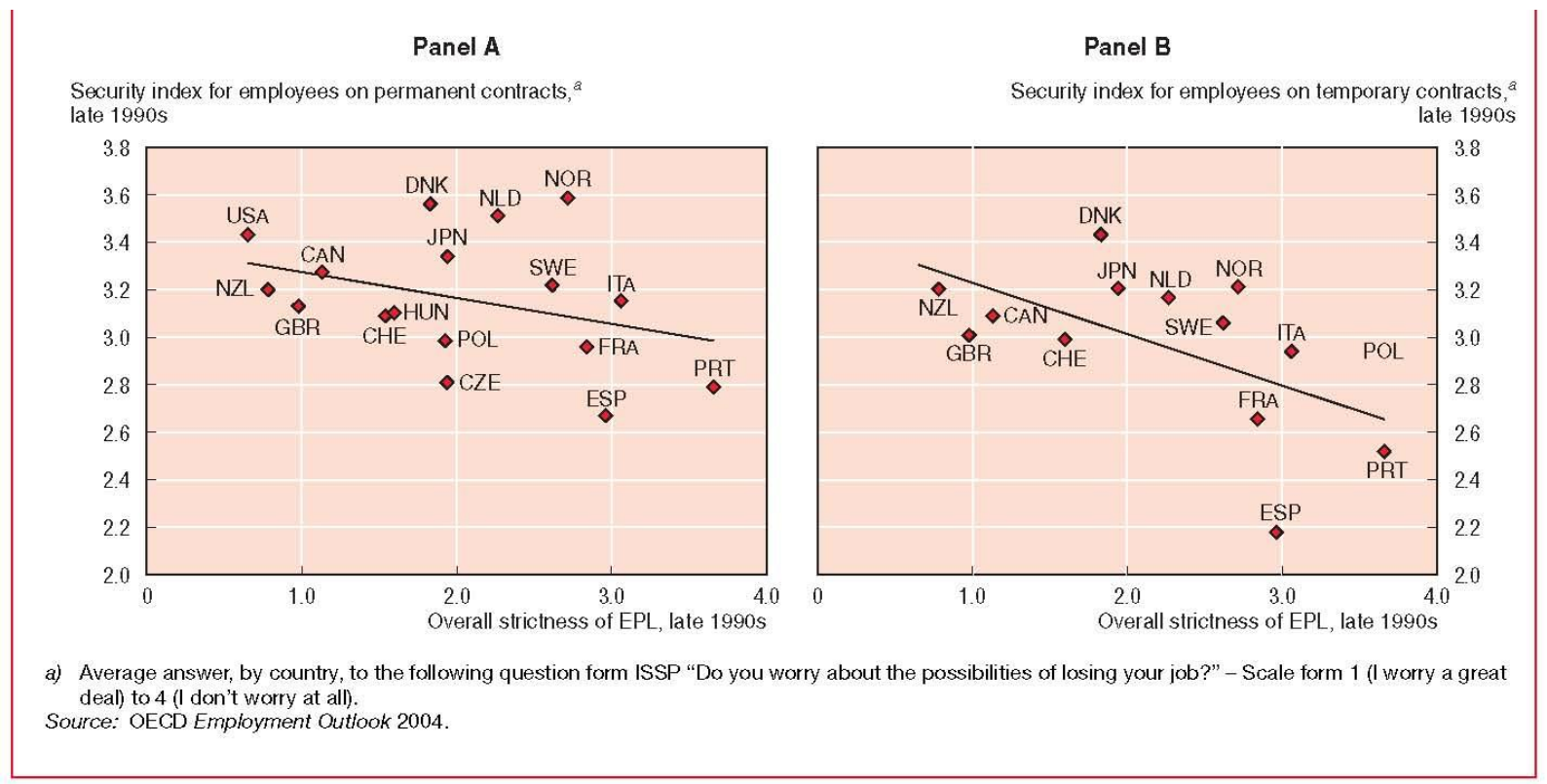

Authorities must seek to develop, in a harmonious way, the three dimensions of the labour market security. This conception of the labour market is presently applied in some Scandinavian countries and is known under the name of flexisecurity. It is a way to foster labour market security while maintaining a sufficiently-mobile labour force. The Scandinavian model is very often regarded as simultaneously efficient and equitable.

\footnotetext{
${ }^{34}$ OECD Observer (September 2004).

${ }^{35}$ Idem
} 
Flexisecurity represents a policy strategy that can be defined as follows: ${ }^{36}$ "[flexisecurity] attempts, synchronically and in a coordinated way, to enhance the flexibility of labour markets, work organization and labour relations on the one hand, and to enhance security - employment security and social security - notably for weaker groups in and outside the labour market on the other hand." There exists however many variations of flexisecurity depending on the weight which is allotted to each of the two elements that make up this policy strategy.

Public organizations of assistance in finding employment could be replaced by firms specialized in lifelong learning, training, recycling, and placement of workers. These competitive-sector organizations would find in their best interest, thanks to incentive-compatible contracting clauses, to provide high-quality services in the short- and long-term. It is possible to imagine that each worker would choose to be affiliated with a lifelong learning and training competitivesector organization in order to continuously be aware of the desirability of acquiring new or maintaining competencies, as a strategy against significant spells of unemployment. Constantly in competition and financially encouraged to obtain high placement and success rates, these lifelong learning and training competitive-sector organizations will tend to provide services of high quality given the labour markets' demand for workers of different types. Once financial incentive mechanisms are put into place, the government sector will let firms compete for government contracts and propose lifelong learning and training methods that seem most effective. The pursuit of generic policies and programmes will ensure an efficient level of modularity and experimentation to identify best practices. No centralized system of bureaucratic commands and controls can achieve such objectives as efficiently as the competitive system to be put in place. The main reason for that is by now well known: the quantity of information to be collected, handled and processed is so huge that any centralized system is bound to fail.

It bears repeating that the links between the creation, sharing and redistribution of wealth are complex but need not be in conflict, provided that certain determining factors are well understood. We must find a way to integrate objectives of efficiency, effectiveness, and social cohesion and, in so doing, objectives of properly-understood wealth creation and redistribution.

\footnotetext{
${ }^{36}$ See T. Wilthagen (2002), “Managing Social Risks with Transitional Labour Markets”, in Mosley, H., J. O’Reilly and K. Schönmann, eds., Labour Markets, Gender and Institutional Change, Cheltenham: Edward Elgar.
} 
There are two reasons why there exists a level of inequality in the sharing of income or wealth that enhances the well-being of everyone. First, incentives for creativity, innovation and entrepreneurship are a fundamental and essential factor in economic development. They are derived largely from the fact that the fruit of these developments can accrue in the short term to those directly responsible for them, namely, the creators, innovators and entrepreneurs. This is the basis of intellectual property protection, in different forms, such as patents and copyrights. Second, for the results of this creation and innovation to be fruitfully applied and commercialized, highly trained and skilled human resources are required. At a time of accelerated wealth creation, pressure on these resources pushes up their value compared to that of basic human resources with lower levels of skills and competencies in putting those new production technologies and organizational forms to work. This provides a powerful incentive to acquire such skills.

This phenomenon strongly suggests that wealth can be redistributed in an effective and sustainable way only through the adaptation of the portfolio of skills possessed by individuals, thereby raising their market value, that is, their value to fellow citizens. It is by establishing institutions and mechanisms promoting this continuous, rapid and orderly adaptation of skill portfolios that governments can best foster a proper connection between wealth creation and its responsible redistribution. The best way to redistribute wealth in a durable way is to promote the participation of each and everyone in its creation.

\section{REFORMING THE EDUCATION SECTOR}

In Sweden, education was another sector heavily regulated and one that has since changed substantially with the round of liberalization in the 1990s. Starting in 1991, the Swedish educational system was reorganized around three main reforms, most notably the adoption of a school voucher program. First, while educational content remained nationally legislated, municipalities, instead of states, were now in charge of running the school system. Second, independent schools approved by the National Agency for Education were given equal public funding as municipal public schools. These independent institutions are allowed to make profit by managing their schools in a more cost-effective way and not charging extra fees. Third, 
parents were given freedom of school choice. ${ }^{37}$ Using the voucher system, parents not only decide which schools their children attend but they also influence which ones receive funding.

Under the Education Act, all Swedish pupils are provided access to education equal in value irrespective of their school choice or geographic location in the country. Students are admitted on a first-come, first-served basis without any other requirements. The cost of education is free to all participants. The Swedish school system is funded through tax revenues of municipal and central governments. At the same time, an equalization system to even financial conditions of all municipalities using charges and grants has been put in place since 2005. In 2008, 140 municipalities received higher grants due to their disadvantageous cost structure, and 150 municipalities had a deduction in their general grant due to their favourable cost structure. ${ }^{38}$

The underlying goal for the Swedish education structure is to improve overall educational outcomes. Public schools compete with independent schools for students and have therefore strong incentives to increase the quality of provided education by means of organization or pedagogy. For instance, schools are continuously looking into improving their method of teaching through the use of technology by making available online the entire syllabus and elogbook progress. Moreover, the presence of different types of school allows the various needs and preferences of pupils to be met.

Since the voucher program's inception, the number of independent schools has grown substantially. Independent schools are mostly owned by corporations which can run several schools. From 1992 to 2004, the total increase of independent compulsory schools amounted to 469 new schools, representing an increase of $438 \% .{ }^{39}$ There is also evidence that municipal enrolments declined during this period. Independent schools were shown to be smaller in size and provide education to a higher proportion of students with special needs than municipal schools. ${ }^{40}$ Municipal schools seem to have benefited from the liberalized structure as national

\footnotetext{
${ }^{37}$ Anders Böhlmark and Mikael Lindahl, Does School Privatization Improve Educational Achievement? Evidence from Sweden's Voucher Reform, The Institute for the Study of Labour (IZA), Discussion Paper No. 3691, September 2008.

${ }^{38}$ Swedish Ministry of Education and Research, Funding of the Swedish school system, March 2008.

${ }^{39}$ Hepburn, C. and Merryfield, J., School Choice in Sweden - Lessons for Canada, Fraser Institute Occasional Paper, November 2006.

${ }^{40}$ Frontier Centre for Public Policy, Sweden's School Voucher Program Choice and competition improve all schools, public and private, May 2005.
} 
education results keep improving. The OECD reported in 2005, that Sweden's private school results are $8 \%$ better than public school results. ${ }^{41}$ In 2008 , the proportion of students privately educated continued its steep upward trend to now reach more than $10 \% .{ }^{42}$

One of the critics of the Swedish system pertains to the inability of willing parents to pay for additional education benefits as schools are prohibited to charge fees. This forgone supplemental education might be detrimental to certain groups of students. Another unintended consequence of proscribing fees is limiting the level of innovation in education using co-curricular programs.

Nevertheless, the Swedish educational program still benefits from wide public support and is sought after in other countries. In North America, the voucher system remain subject of debates both in Canada and in the US as it has only been in use in a few states in the US. But support for reforms in public education has been building up for obvious reasons of cost-consciousness for taxpayer money and the need for higher educational attainment. Some steps have been taken towards reform. Charter schools, which are publicly funded through a district school board or education ministry and are operating semi-autonomously, have been implemented in the US (mainly in California and Minnesota) and in Canada (only in Alberta). ${ }^{43}$ In Ontario, tax credits have been extended to parents with children in private schools. ${ }^{44}$

Teachers' unions are often refractory to the idea of privatizing education. Introducing competition in the school system will likely lessen the power of these organizations to influence the national education agenda. Opponents of reform are also resistant to rewarding merit and excellence in teaching. But several studies have pointed out that creating competition among schools can improve teaching standards and the use of public resources. Again, the case of Sweden which has been able to win over unions and increase educational outcomes is an eloquent example. In a recent New York Times video op-ed, Swedish education authorities and

\footnotetext{
${ }^{41}$ OECD, OECD's Education at a Glance: OECD Indicators 2005, OECD 2005.

${ }^{42}$ The Economist, The Swedish Model, June 2008.

${ }^{43}$ The Canadian Encyclopedia. Information available at: http://www.thecanadianencyclopedia.com/index.cfm?PgNm=TCE\&Params=A1ARTA0010090

${ }^{44}$ Frontier Center for Public Policy, School Vouchers in Sweden, May 2005. 
teachers, recognize that a monopoly of public education could not provide high quality education for all children. ${ }^{45}$

Another compelling reason for reform in public education is global competition. Over the last years, Asian countries have been leading their north-American counterparts in international tests of math and science. ${ }^{46}$ This has propelled the debate to another level, that of the long-term competitiveness of trailing countries in education. In a global world, knowledge has become a strong competitive advantage.

In the US, President Obama is considering the reform of public education around five "pillars": early childhood education, better standards and assessments, better teachers, more charter schools, and improved federal college assistance. However, supporters of education reform noted that while these measures will benefit education, they omit the parental school choice option. ${ }^{47}$ In Canada, as well as in the US, the debate over education reforms continues.

Past experiences in other countries have yielded important gains in educational attainment by introducing a market-based education reform through the establishment of pampered competition and decentralization of the system. This holds especially true for education at the primary and secondary levels for which a system of vouchers together with the fair and equitable subsidization of independent schools competing with traditional public schools, has proven effective and beneficial in many cases.

\section{LESSONS FOR CANADA}

Despite significant increases in public spending on primary and secondary education in OECD countries, concerns linger about both the efficiency and effectiveness of the school sector. In response to these concerns, governments around the world have introduced a range of strategies aimed at improving the financing and delivery of school-level education. These strategies have included reductions in class sizes, increases in teacher salaries, curriculum reforms and market-

\footnotetext{
${ }^{45}$ New York Times Video Op-ed available at: http://video.nytimes.com/video/2009/03/15/opinion/1194838660912/op-ed-sweden-s-choice.html

${ }^{46}$ Trends in International Mathematics and Science Study, information available at: http://timssandpirls.bc.edu/TIMSS2007/mathreport.html

${ }^{47}$ Chaney, R., President Obama's Education Vision Falls Short, Pacific Research Institute, April 2009. 
based reforms that involve the decentralization of decision-making on education and encourage choice and competition.

We discuss here one particular form of market-based education reform that has become increasingly popular in recent decades - the decentralization of school management (also called school-based management). Decentralization of school management can take many forms and has appeared in a variety of guises in different countries, besides Sweden. Among the most prominent examples have been the charter schools in several US states (and to a much more limited extent, in Alberta), the Tomorrow's Schools reforms in New Zealand, and grantmaintained and foundation schools in the UK.

School-based management can be defined as the systematic decentralization to the school level of authority and responsibility to make decisions on significant matters related to school operations within a centrally determined framework of goals, policies, curriculum, standards, and accountability. ${ }^{48}$ School decision-making is often broken down into different domains, the four most important being personnel management (appointing and dismissing teachers, establishing salaries), financial resources (school budget formulation), student policies (disciplinary and assessment policies) and curriculum and instruction (course content and textbooks). Infrastructure development and maintenance as well as security are other domains of interest.

The main reason put forward to support decentralization is that those closest to teachers and parents are best placed to make decisions on the organization of school resources to meet the needs of students and the wider community. Charter schools represent one of the most significant examples of school self-management in the US. Charter schools are secular public schools that are not subject to many of the regulations applying to regular public schools, such as geographic enrolment restrictions and teacher union contracts. The charter that establishes a school is a performance contract that details the school's mission, program, goals, students served, methods of assessment and ways in which success will be measured. Charter schools can be managed by the community group that holds the charter or by a for-profit or not-for-profit school manager.

\footnotetext{
${ }^{48}$ Caldwell, Brian J. (2005) School-based Management, International Institute for Education Planning, UNESCO, Paris, p. 1. 
Since the mid-1990s, Alberta has operated a system of charter schools which is similar to that in the United States. However, the initiative is small in scale, with the number of charter schools that can exist at any one time limited to 15 . Alberta remains the only province in Canada to have charter schools. They operate in a similar manner to those in the US: they are secular, publicly funded, cannot charge tuition fees and enjoy greater autonomy than regular public schools. They cannot directly employ unionized teachers but can second them from the school district. Charter schools report directly to the provincial government, rather than to the local school district. Charter schools can have a particular focus, such as the arts or gifted children. ${ }^{49}$ The rather fast growth of Charter schools in the US is a clear sign that stakeholders are increasingly satisfied with their performance. ${ }^{50}$

The New Zealand Tomorrow's Schools reforms of 1989 ushered in a new era of self-managing schools by creating a more competitive environment for schools within the public sector, increasing choice for all and particularly for students from low-income families, eliminating an entire level of education bureaucracy, providing communities with greater voice in schooling, and giving schools the freedom and autonomy to better meet the needs of local communities.

Cross-country evidence from successive Progress In Student Achievement (PISA) studies suggests that education systems that devolve more responsibility to schools in areas concerning budget allocations within schools, the appointment of teachers, course offerings and disciplinary matters get better results. For example, data suggest that in those countries in which principals report, on average, higher degrees of autonomy in certain aspects of school management the average performance in mathematics tended to be higher. ${ }^{51}$ Similarly, in those countries in which principals report greater school autonomy with regard to choice of courses, the average performance on the combined reading literacy scale tended to be higher. ${ }^{52}$ The OECD is careful to point out however that correlation is not causality.

\footnotetext{
${ }^{49}$ Government of Alberta: http://www.learning.gov.ab.ca/educationsystem/charter_hndbk.pdf

50 Measuring parents' satisfaction in schools requires advanced econometric analysis to control for the multiple biases that may be present. See J. Buckley and M. Schneider, "Are Charter School Parents More Satisfied With Schools? Evidence from Washington, DC," Peabody Journal of Education 87(1), 57-78.

51 OECD, Learning for Tomorrow's World: First Results from PISA 2003, Programme for International Student Assessment, 2004, p. 236, http://www.oecd.org/dataoecd/1/60/34002216.pdf.

52 OECD, Knowledge and Skills for Life: First Results from PISA 2000, Programme for International Student Assessment, 2001, p 178, http://www.oecd.org/dataoecd/44/53/33691596.pdf.
} 
Decentralization is no panacea for improving education outcomes. To many supporters of market-based reforms in education, decentralization through charter schools for example, is an incomplete reform. However, if implemented carefully and with clear objectives, it can provide governments with a vehicle for achieving a number of policy goals, including increasing community ownership of schools, improving student learning outcomes, and providing more streamlined administration of the education system.

In a significant number of advanced countries, education and lifelong training have become a sector where the wasting of resources is ubiquitous, in particular in the formal education system. Excessive bureaucratic control, both between and within organizations, implies poor reactivity to changes in labour markets and strong hostility to explicit, open, transparent, and credible evaluation of the performance of the system and sub-systems. More competitive mechanisms stand a much better chance of success by making a broad central place to modularity, freedom, high intensity incentives, and efficient allocation and coordination, thereby improving the likelihood of achieving success and improving the overall performance of the system. Education is a service that is too complex and too diversified, both in demand and supply, to be efficiently produced and distributed in a centralized fashion.

The overall design and setting of performance objectives must be a prime responsibility of the State while the production, distribution and delivery of education and lifelong learning services could be more efficiently achieved by competitive providers, appropriately induced to meet the objectives embedded in properly designed contracts between the providers and the State.

Some observers claim that problems in the education system could be solved by an injection of additional funds and resources. In many cases, it is rather the organization of the system that must be re-examined. Difficulties in the educational sector are most often due to an inefficient system of production, distribution and delivery of educational goods and services. A better use of the resources presently dedicated to education services could go a long way in solving the endemic problems of education systems. A better use of resources means and requires a more efficient division of responsibilities between the State and competitive sector organizations and a systematic recourse to competitive processes and prices to guide individual choices and social investments. 


\section{FRENCH REGULATORY REFORMS IN TELECOMMUNICATIONS AND HEALTH CARE}

A series of economic challenges stemming from increased competition on global markets, the unsustainability of welfare states...have confronted authorities in Old Europe with the urgency of reform or the threat of decline. On another front, the inception of the European Union (EU) raised pressure on national policymakers to comply with mandatory regulations in several sectors. Like elsewhere in Western Europe, reforms to increase competition have stirred much controversy in France but were nevertheless implemented in the face of European integration and globalization. We review the relevance of several reforms in the vital sectors of telecommunications and health care in France.

\section{THE TELECOMMUNICATIONS SECTOR}

The French telecommunications sector underwent several changes over the last decade. The main factors that led to such reforms could be summarized into three major dynamics.

- First, the telecommunications sector is one that has been highly impacted by technological progress. Many recognize the economies of scale resulting from the use of advanced technologies such as fibre-optics at the microeconomic and macroeconomic levels. A dynamic telecommunications infrastructure is credited with the potential to boost economic activity and competitiveness. Entry barriers into the telecommunications sector were therefore lowered for new market players.

- Second, French authorities faced increased pressure to liberalize telecommunication markets in order to reap the benefits of competition and tackle budget deficits. Early proponents of pro-competition reforms in telecommunications were met with scepticism from authorities and opposition from labour unions. However, the government-controlled sector placed consumers at a competitive disadvantage for new services. 
- Third, and most importantly, adherence to EU legislation on telecom provided political support for previously unaccepted changes and made imperative a profound reform of the French telecom system.

France's telecom sector is regulated by three institutions. The Autorité de Régulation des Communications Électroniques et des Postes (ARCEP) is an independent regulatory body whose main role is to ensure that an effective level of competition is exercised on the different market segments. ARCEP may impose certain obligations to operators or markets insufficiently competitive. The Autorite de la Concurrence is the authority mandating competition rules on every market including that of telecommunications. The competition authority has the power to investigate competition issues and impose financial penalties and injunctions. Finally, policy decisions such as the establishment of pricing guidelines in different markets lies under the responsibility of the Ministry of economy, industry and labour.

Until its initial public offering in 1996, France Telecom (FT) held a monopoly as the sole provider of telecom services and networks. Moves towards privatization were taken relatively slowly. The civil servant status of most employees created a major hurdle for denationalization and government measures such as a favourable tax regime were brought under investigation by the European Commission. It was not until 2004 that the French government retained less than $50 \%$ of FT's ownership.

The mobile telephony market was the earliest sector to experience competition in 1987 when Société Française de Radiotéléphonie (SFR) was licensed for GSM to compete with France Telecom Mobiles (later known as Orange), an affiliate of the state-owned incumbent FT. During this period, competition between SFR and FT revolved around the expansion of their network's coverage and customer base through pricing policies and differentiation in tariff plans. This mobile duopoly structure was broken in 1996 by the entry of a third GSM operator, Bouygues Telecom. As a result, the nature of the competition was changed towards more technology innovation and service diversification. The arrival of Bouygues Telecom also accelerated the growth of mobile penetration rates from $4.2 \%$ in 1996 to $69.1 \%$ in $2003 .{ }^{53}$ However, the French penetration rates for mobile services were still much lower than that of the EU average estimated

\footnotetext{
${ }^{53}$ Organization for Economic Cooperation and Development, Reviews of Regulatory Reform, Regulatory Reform in France. Regulatory Reform in the Telecommunications Sector, OECD 2003. 
at over $80 \%$ at the end of 2003. During the 2001-2002 periods, market shares did not considerably vary among the three mobile operators, in sharp contrast with the previous period during which Bouygues Telecom experienced the strongest growth in sales than its competitors. In 2003, FT had a stabilized market share of $48.9 \%$, followed respectively by SFR with the share of $35.4 \%$ and Bouygues with $15.6 \% .^{54}$ By then, the Autorité de la Concurrence had recommended the launch of an immediate investigation and consumer associations had brought complaints before ARCEP about the pricing structure of calling times and fixed to mobile calls. In December 2005, after a thorough inquiry, ARCEP fined the three network operators FT's Orange, SFR and Bouygues Telecom a record $€ 534$ million for anticompetitive agreements. ${ }^{55}$ The ARCEP ruled that the three had shared confidential information between 1997 and 2003 and that they entered into a market sharing agreement from 2000 and 2002. The Court of Appeal later upheld the ARCEP decisions. These developments, combined with the need to continuously keep pace with technology and France's unenviable standings in terms of telecoms in the EU zone, justified the use of new initiatives to expand competition in the mobile market.

France's first attempts to auction licenses fell into disarray with the non-participation of major players. The license contest in France is different from that of other European countries as authorities set a price for the licenses before the auction. Nevertheless in 2001, third-generation (3G) licenses were awarded to FT and SFR. The following year, license requirements were lowered and Bouygues, the sole applicant in the contest, was granted a $3 \mathrm{G}$ license. More recently, French authorities announced the auction process for a fourth $3 \mathrm{G}$ mobile license due to be awarded in 2010 with a significant drop on the asking price.

In a subsequent move to increase competition, the ARCEP allowed the provision of mobile services by mobile virtual network operators (MVNOs) in 2004. MVNOs lease the licensed spectrum and infrastructure of the three incumbent providers to resell wireless services. However, MVNOs were not able to gain significant market shares due to several factors. Contracts with hosting operators were described as deterrent to the growth of MVNOs as they impose restrictions on prices, services, and investments. In 2008, the ARCEP recommended the

\footnotetext{
${ }^{54}$ Organization for Economic Cooperation and Development, Reviews of Regulatory Reform, Regulatory Reform in France. Regulatory Reform in the Telecommunications Sector, OECD 2003.

${ }^{55}$ Conseil de la concurrence, Décision no. 05-D-65 du 30 novembre 2005 relative à des pratiques constatées dans le secteur de la téléphonie mobile. Available at : www.arcep.fr
} 
relaxation of rules under which MVNOs operate to further foster competition and increase mobile penetration rates. As of June 2009, France has 11 MVNOs whose total mobile market is estimated at $6.02 \%$ in the residential market. ${ }^{56}$

Along with the launch of MVNOs, mobile portability was introduced in France in 2003 following the European Union directives. The intended results were to increase competition among network operators and new entrants and to exert downward pressure on prices. However, there is little evidence on the impact of this new policy and few French subscribers have ported their mobile number. ${ }^{57}$

French authorities are continuously reviewing policies pertaining to the mobile telephony market. Latest decisions include the imposition of price-caps on mobile termination rates, a reform of the structure of calls to special services and value-added services with more pricing transparency and compliance with a professional code of conduct. ${ }^{58}$

The telecom regulator plays a critical role in creating a balance between fair competition among operators and consumers' interest. As such, the Autorité de la Concurrence was given strengthened powers and means to investigate independently and issue views on any competition matter on its own initiative. This has largely contributed to restraining the anti-competitive behaviour on the telecom markets and helped in pursuing the development of a competition culture.

\footnotetext{
${ }^{56}$ Information available at: www.arcep.fr. Opérateurs de réseau mobile de métropole : Orange France, Société Française du Radiotéléphone (SFR), Bouygues Telecom et MVNO actifs contrôlés par les opérateurs de réseau et comptabilisés comme tels : Débitel, Ten et Neuf Cegetel. Opérateurs mobiles virtuels de métropole indépendants des ORM et actifs sur le trimestre : Afone, Auchan Télécom, Carrefour mobile, Coriolis, E-plus, Mobisud, NRJ Mobile, Numéricable, Omer Telecom, Tele2, Transatel. Opérateurs de réseau mobiles outre-mer : Orange Caraïbe, filiale d'Orange France ; Orange Réunion, filiale d'Orange France ; Société Réunionnaise du Radiotéléphone (SRR), y compris sous la marque Mayotte Télécom Mobile à Mayotte, filiale de SFR ; Digicel AFG ; SAS SPM, filiale d'Orange Caraïbe à Saint Pierre et Miquelon ; Dauphin Telecom ; Outremer Telecom ; UTS Caraïbe.

${ }^{57}$ Haucap, Justus, Buehler, Stefan and Dewenter, Ralf. "Mobile Number Portability in Europe" (July 2005). Available at SSRN: http://ssrn.com/abstract $=765224$

${ }^{58}$ Autorité de Régulations des Communications et des Postes (ARCEP) : www.arcep.fr

Page $\mid 30$
} 


\section{LESSONS FOR CANADA}

Telecommunications and more generally information and communication technologies (ICT) constitute the backbone of our societies. It is of utmost importance for the well being, present and future, of modern societies to have an efficient web of telecommunications chains and networks. Such a web is essential for social cohesion, productivity gains, innovation and commercialization, and for reaching the highest level of humanist economic growth.

The development of telecommunications is significantly influenced by the regulatory framework put in place to oversee the evolution of this web towards a competitive system through policies aimed at protecting efficient newcomers from predatory incumbents and to protect the public against the capacity of large firms to exercise market power. If and when the level of competition is deemed sufficient, specific economic regulation is expected to disappear in favour of general competition or antitrust policy while technical, architectural or design regulation and coordination will subsist.

When is the level of competition in a national telecommunications industry sufficient? If it is not, then when will it be, that is, what value of which indicators will tell us that its time has come? The answers to those questions are vital for any society since too much economic regulation for too long as well as too little economic regulation for too short a time generate important social costs in terms of consumer welfare, productivity, innovation, and growth.

We must develop a methodological framework, which will allow a proper characterization of the level of competition and renew our approach to regulation in this most important sector. We must address major concerns of the regulators regarding two "factual measurements," first the small number of competitors in some markets and second the high market shares captured by the incumbent firms.

The above "factual measurements" are poor indicators of the level of competitive pressures in those markets. Indeed, those facts may be credible indicators that competitive pressures are relatively intense, so much so that entry strategies by newcomers are not profitable. The traditional measures of competition based on market shares are inadequate because this industry has more characteristics of an emerging industry than of a mature industry. 
The current approach to economic regulation, mainly based on the tight control of incumbent local exchange carriers (ILEC) and light-handed surveillance of competitive local exchange carriers (CLEC), has run its course as market delineations become rapidly blurred.

The new regulatory framework should rest on three specific principles of economic performance:

- The pursuit of a dynamic regulatory approach based on implementing proper competition processes and information systems.

- The promotion of competition through proper incentives ensuring:

○ Dynamically efficient inter-access prices and conditions

- Efficient investment programs in network maintenance and development.

- The design of non predatory pricing rules through full cost sharing to promote the emergence of a more competitive industry even if such rules reduce static effectiveness (measuring how close the outcomes and results are to the objectives) and efficiency (measuring how much resources were used to reach or deliver the results).

If the government/regulator wishes to adopt a pro-active strategy to favour the emergence of competition, based on the fact or belief that incumbents have an "unfair" advantage, then the preferred policy is a direct incentive subsidy, such as a generous but deferred investment grant or tax credit to be paid at some time in the future conditional on the entrant's capture of a predetermined market share. All potential entrants, and only those, with superior products or services, and/or superior technology, and/or better quality consumer service, who believe they can compete with and displace the incumbent one way or another, will enter or consider entering the industry. Inefficient competitors, fly-by-night operators and fast-buck seekers will stay out. Consumers and customers will reap the benefits of performance-enhancing competition through proper creative destruction.

To achieve a proper balance between short run (static) and long run (dynamic) goals, regulators must rely on competitive processes, that is, they must make sure that their interventions are not aimed at micro-managing prices and quantities but rather at making sure that those prices and 
quantities emerge from a competitive environment. Micro-managing prices and quantities is very much reminiscent of the old regulatory framework (rate-of-return regulation for instance) that led the regulator to discover through adversarial proceedings the "true" cost functions of the firms. We know now that this objective was futile: economic costs are not accounting costs. Exerting a proper level of competitive pressures is the only way to induce firms to really minimize the costs of their portfolio of goods and services, that is, to make the accounting costs close or equal to the economic costs.

The possibility and desirability to better inform customers about the characteristics, including pricing, of different (packages of) telecommunications goods and services should, in the context of an emerging industry such as telecommunications, be a well-understood role of the regulator. This regulation by information approach is not new but it is too often neglected as if customers of complex goods and services were individually able to make and understand comparisons of pricing and other characteristics such as connectivity, flexibility, safety, dependability, accessibility, capacity, and user-friendliness of telecommunications services. In an industry such as telecommunications, the generation and presentation of such information in a user-friendly way should be a role and responsibility of the regulator, at least till the customers develop such a capability of their own. Asking the regulator to assume such a responsibility could prove very important for economic performance and political acceptability during the transitory period towards a complete deregulation of the telecommunications industry.

Regulators generally recognize that substituting competition mechanisms for costly imperfect regulation could improve cost effectiveness as well as allocative performance. But for network industries, it is not necessarily desirable to introduce competition in all segments. Some segments of a network, which are essential inputs for the potentially competitive segments, may be subject to significant economies of scale. These so-called essential facilities, specific to a given technology, could remain price regulated as long as alternative technologies, allowing those segments to be by-passed are not available. For instance, the local wireline may still represent a non-standard natural monopoly. Even though it is challenged by competing technologies, it would not make sense to duplicate the last mile wireline connection to homes 
and businesses. What is needed is open (inter)access to all essential facilities on all technologies at proper prices and conditions. ${ }^{59}$

The promotion of performance in network development investments is a role and a responsibility that the telecommunications regulator should assume. The main reasons are threefold:

- Investments in network development are typically large long-term irreversible investments with significant economies of scale making a given platform a non standard natural monopoly;

- The different network development strategies offer significantly different levels of embedded managerial flexibility to delay or advance the development timing (to slow down or speed up the pace of development), to increase or decrease the planned network size and scope, and to raise or reduce the planned quality of the network infrastructure as new information on significantly volatile demands and costs is gathered over time;

- The volatility of demand and costs together with the relative embedded managerial flexibility and the significant irreversibility of investments in network development require new evaluation methodologies (real options valuation), which are still underused by network operators.

In such a context, the regulator must make sure that inter-access to essential facilities is available, at proper non-discriminatory conditions and prices, to foster entry by more efficient providers. ${ }^{60}$ The regulator must also recognize that the proper non-discriminatory conditions and prices must account for the real options that are exercised, as the network is being built or developed. ${ }^{61}$ Eventually, the network developing firm is stuck with the technological

\footnotetext{
${ }^{59}$ In proceedings under competition law, the definition and characterization of "essential facilities" remain a hotly debated issue.

${ }^{60}$ For a presentation and discussion of access pricing rules, see Marcel Boyer and Jacques Robert, "Competition and Access in Electricity Markets: ECPR, Global Price Cap and Auctions," pp. 47-74 in Georges Zaccour (ed.), Deregulation of Electric Utilities, Kluwer Academic Pub., 1998; and also Marcel Boyer, Michael Benitah and Weihao Sun, "Real Options, Network Development and Network Access", WIK NETCONOMICA 2008 Conference on "Current Issues in Network Economics: Regulatory Risk, Cost of Capital and Investment Incentives," September 2008, Königswinter, Germany.

${ }^{61}$ For a discussion of the real options approach to evaluating investment decisions, see Marcel Boyer, Peter Christofferson, Pierre Lasserre, and Andrey Pavlov, "Value Creation, Risk Management and Real Options," Icfaian Journal Of Management Research, October 2004 (CIRANO 2003RB-02). For a discussion of real options and
} 
characteristics of its realized network. Exercising those real options can represent a significant cost in network development and must therefore be accounted for in determining the proper nondiscriminatory access prices and conditions that will govern the use of the incumbent's network by competitors. Unless a proper account is made of those real options related costs, the development and maintenance of the telecommunications networks are likely to be inefficient, thereby imposing significant real costs on society.

This leads to two important observations. First, in reviewing pricing rules for inter-access to networks, the regulators must consider not only the development of competing networks on alternative technological platforms but also in each case the implicit costs of the real options exercised in developing the network infrastructures. Second, in reviewing the rules of competition between networks, the regulators should make explicit and transparent the procompetition special treatment that it wishes to grant to some competitors rather than directly impose price and technology controls on others.

In a standard natural monopoly industry, profits are likely to rise rapidly when the market expands since revenues then increase linearly or proportionately with the number of subscribers while costs increase typically very slowly due to the presence of economies of scale, economies of scope and network economies. The increase in profits means an increased rate of return on capital, exceeding over time by a significant margin the opportunity cost of capital of the firm. In any normal industry, this increased profitability would favour the entry of additional firms into the industry, but not necessarily in a natural monopoly industry. In this latter type of industry, the potential entrants understand that what is important and crucial for them is not the price they observe or the profits the incumbent firm is presently enjoying but rather the price and profits that they will be experiencing if and when they enter the market and compete with the incumbent firm.

It is post-entry goods and services prices that preoccupy the potential entrants, not actual preentry prices. In particular, if it is understood that regulators are going to control pre-entry prices at a relatively low level but that they will let prices be freely determined once new competitors

access pricing in network industries, see Jerry Hausman and Stewart Myers, "Regulating the United States Railroads: The Effects of Sunk Costs and Asymmetric Risk," Journal of Regulatory Economics 22(3), 287-310, 2002. 
have entered the market, then observed pre-entry prices will have no effect on the decision to enter or not. Potential entrants will evaluate what competitive post-entry prices are likely to be and then decide if those prices justify entry or not.

Those redesigned responsibilities of the regulator are in fact the end point of the sequence of regulatory reforms that have been implemented over the last 15 or 20 years. The telecommunications industry regulator would become a truly pro-competitive watchdog and an integral part of Competition policy implementation.

Although the information gathering, the institutional reforms and the change of minds and attitudes required to implement a true pro-competitive regulatory framework for telecommunications, in particular for the local access markets, represent a sizable and significant undertaking, it is no more and probably much less demanding than the current regulatory framework. Since the change in approach will take some time, it is urgent for national authorities, namely the CRTC and the Competition Bureau, to launch a significant program of research, consultation and transformation, aimed at developing the necessary means and procedures to implement an eventual switch to the new pro-competition rules proposed above.

\section{HEALTH CARE}

Health care in France and in other developed nations is confronted with remarkable challenges: demographic decline, rising medical technology costs, public-sector budget deficits, etc. French authorities have turned to the private sector to improve the delivery of healthcare and establish competition among providers. By most measures, the healthcare system in France is faring better than many of its western counterparts. We describe below some of the interactions between the private and public sectors that well characterize France's health system.

The French health care system is largely known for its universal health coverage principle. Health care insurance is provided on the basis of employment and residential statuses, respectively. Supplementary insurance, covering all or some of the non-reimbursable health expenses by the public system, is also available generally through employers. For certain parts of 
the population, i.e. low-incomes or long-term care beneficiaries, the supplementary insurance is publicly funded under the universal health coverage law. Nearly $92 \%$ of the French population is covered by a private supplemental insurance paid for by patients or their employers or by a supplementary public insurance. ${ }^{62}$

The underlying features of the French health care system are the reimbursement of health care costs incurred by patients and the free choice of public or private health providers. In France, hospitals are attached to local authorities, mainly municipalities and sometimes counties or regional departments. Each hospital is an independent establishment with a financial and administrative autonomy. Private hospitals are for-profit or not-for-profit establishments. In general, larger and teaching hospitals are public while private non-profit hospitals are more specialized care centers and private for-profit hospitals acute and short-term care centers. All hospitals are integrated into the sécurité sociale system.

Under the sécurité sociale, patients receive subsequent direct reimbursements for hospital care services from the health insurance funds. Patients are responsible for a $20 \%$ coinsurance cost for hospital services in addition to a daily copayment in Euros for hospital stays up to a maximum of 30 days. This system of co-payments known as "ticket modérateur" also applies to other health services such as outpatient physician consultations (30\% coinsurance + copayment), dental care (30\% coinsurance), prescription drugs (typically 35\% depending on drug type or listing on the formulary), and etc. Other out-of-pocket costs incurred by patients are typically non-eligible services for reimbursement such as the difference between the reference price on the current formulary and the retail price, a private hospital room, or health care received outside of primary care centers identified for lower reimbursement rates. ${ }^{63}$

Private institutions play an important role in the French health care system. In 2006, there were a total of 1,871 private establishments, among which 1,067 were private for-profit often referred to as private clinics and 804 non-profit institutions. ${ }^{64}$ They offer health services mostly

\footnotetext{
${ }^{62}$ Marcel Boyer, Le secteur privé dans un système de santé public : France et pays nordiques, CIRANO, Février 2008.

${ }^{63}$ Kaiser Family Foundation, Cost Sharing for Health Care: France, Germany, and Switzerland, January 2009.

${ }^{64}$ French Ministry of Health, Youth and Sports, Les établissements de santé: un panorama pour l'année 2006, 2009. 
concentrating on short-term care, surgery and obstetrics, and follow-up care and rehabilitation. In 2007 , health care consumption in the private hospital sector amounted to $€ 16.3$ billion. In 2006, the private for-profit establishments accounted for $37 \%$ of health facilities providing hospitalization and $21 \%$ of full-care hospital beds. The private for-profit sector in French healthcare system is twice as important as that in the United States where for-profit establishments represent $15 \%$ of all hospital and $12 \%$ of all beds. ${ }^{65}$ For instance, in the area of outpatient treatments and cures, for-profit private clinics delivered $32 \%$ of all chemotherapy cures, $55 \%$ of outpatient radiotherapy sessions, and $34 \%$ of dialysis sessions nationwide. ${ }^{66}$ Every year, these for-profit institutions provide health care services to nearly seven million patients while conducting approximately $60 \%$ of all surgeries. ${ }^{67}$

Since 2004, the French health system has introduced further incentives to ensure quality of care. A fee-for-service reimbursement system now enables hospitals to be compensated based on the number and complexity of treated cases. The funding method encourages performance and permanent improvements of health care quality. Patients are informed about the quality of service offered by their health providers through performance indicators established and regularly published by the French Ministry of Health. Health providers have thus no interest in performing poorly, as mediocre care will turn patients away and subsequently reduce funding.

The French system demonstrates that a health care structure with a mix of public and private financing can attain stellar results. Several studies including health reports by the World Health Organization show France leading in public's satisfaction with health system, prenatal and childhood care, and preventable mortality among other measure. ${ }^{68}$ Moreover, these results are achieved without spending substantially more on per-capita health care or health care as a proportion of gross domestic product than other developed countries, like Canada or the US. ${ }^{69}$

\footnotetext{
${ }^{65}$ National Center for Health Statistics, Health, United States, 2007: With Chartbook on Trends in the Health of Americans, U.S. Department of Health and Human Services, 2007, p. 364.

${ }^{66}$ French Ministry of Health, Youth and Sports, Les établissements de santé: un panorama pour l'année 2006, 2009.

${ }^{67}$ French Ministry of Health, Youth and Sports, Les établissements de santé : un panorama pour l'année 2005, 2007.

${ }^{68}$ World Health Organization, information available at www.who.org. European Commission, Health and Longterm Care in the European Union, Special Eurobarometer 283, December 2007. Ellen Nolte and Martin McKee, "Measuring the health of nations: updating an earlier analysis", Health Affairs, Vol. 27 (2008), No. 1, pp. 58-71.

${ }^{69}$ Yanick Labrie and Marcel Boyer, The Private Sector within a Public Health Care System: The French Example, Montreal Economic Institute, Health Care Series, April 2008.
} 
Figure 2: Total Expenditures Per Capita on Health, \$US 2000 Purchasing Power Parity

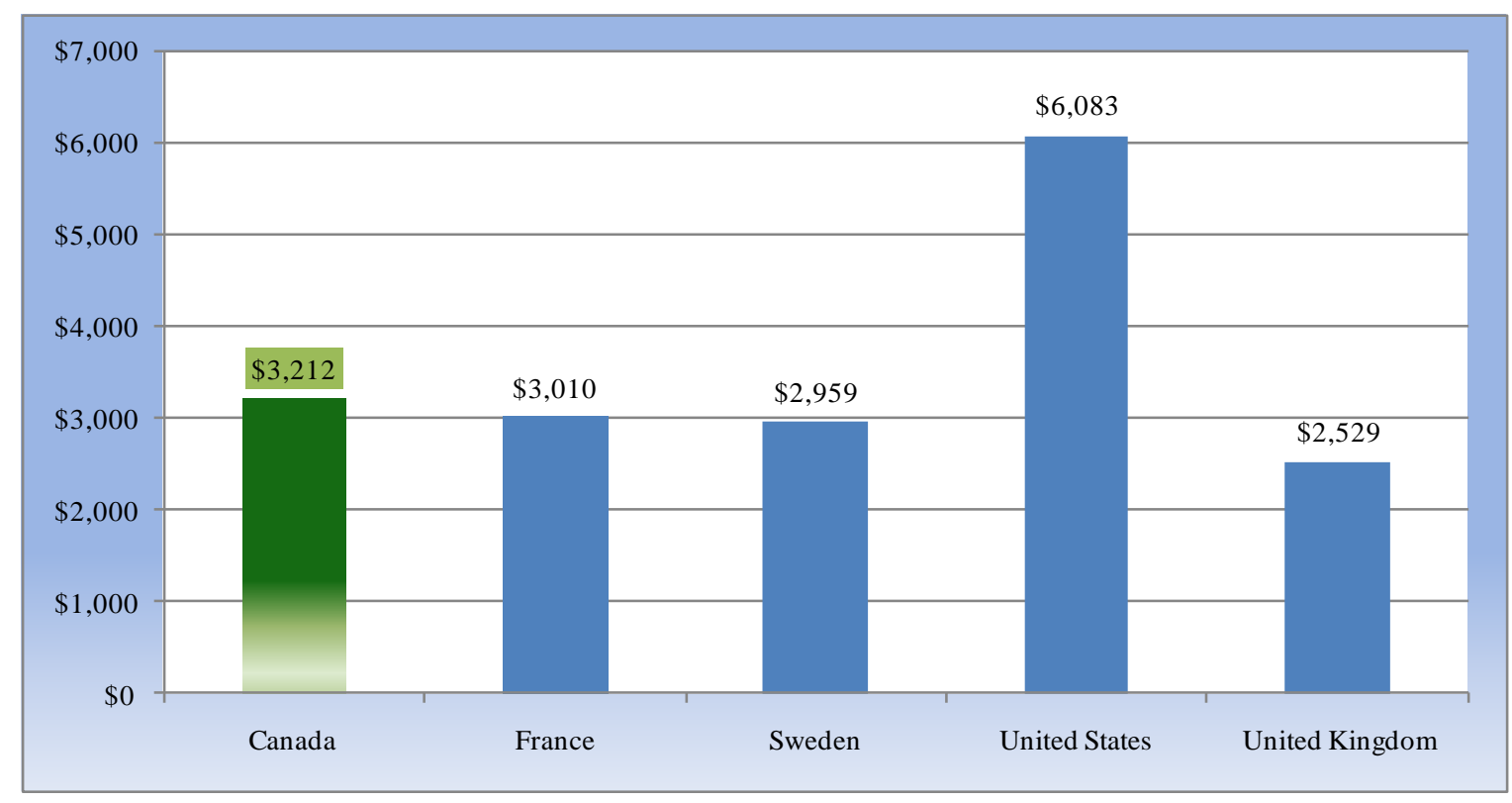

Source: OECD Health Data 2009, June 09

Figure 3: Total expenditures on health (Percentages of gross domestic product)

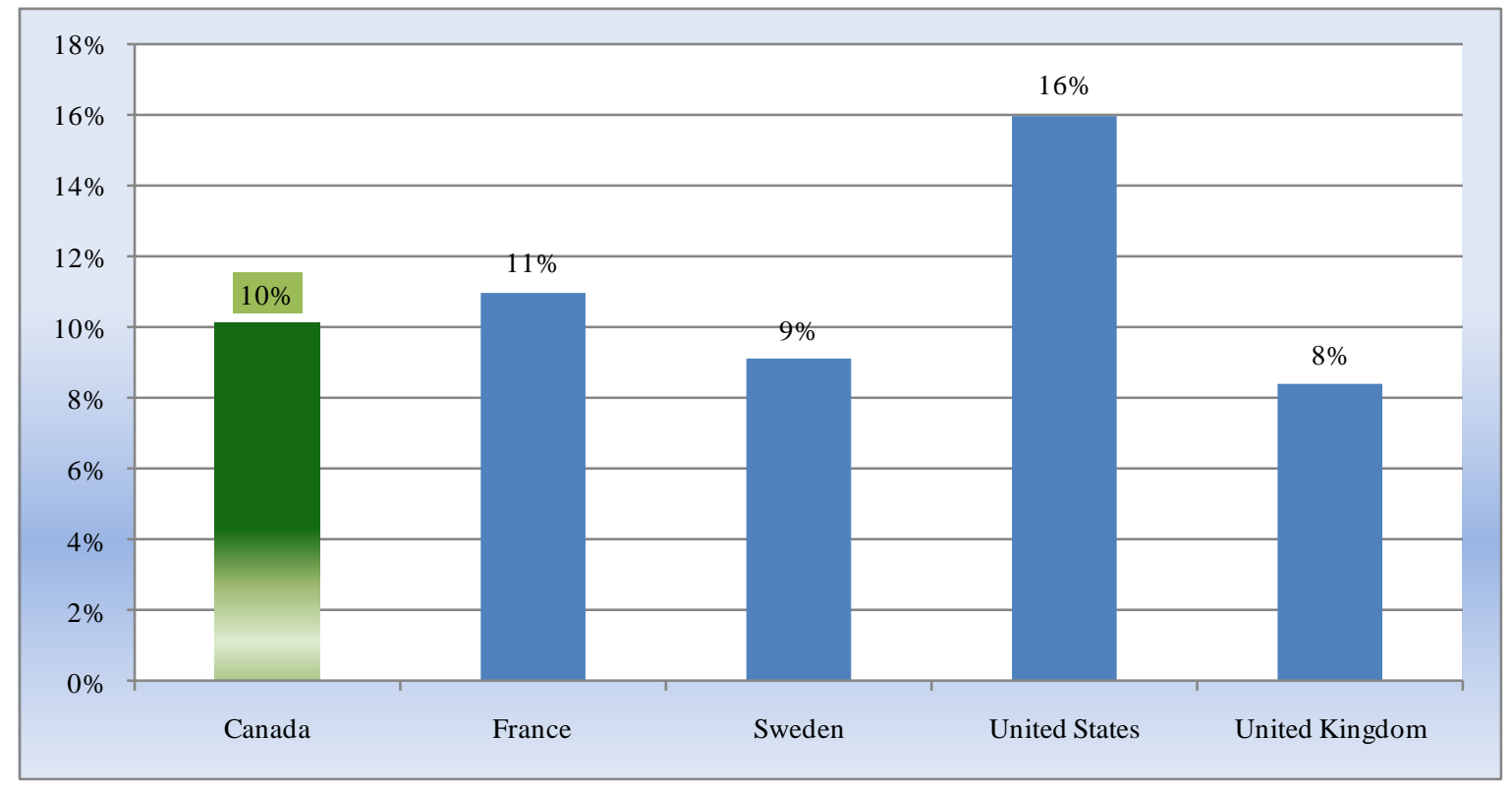

Source: OECD Health Data 2009, June 09

Like many other nations, the French system is confronted with escalating health care expenditures and new measures to tackle down costs will likely arise in the future. But for now, France's health care system characterized by universal health care, a dual public and private 
financing structure, and an enviable quality of health care, can offer valuable lessons for future reforms. Most importantly, the role of private for-profit care providers fully integrated into the public health care system has been shown to be sufficiently significant to alert the public opinion and health care reformers.

\section{LESSONS FOR CANADA}

Health systems not only represent the largest service sector in many countries including Canada but also constitute a crucial factor in the development of social cohesion and inclusion. Its performance, its impact on public finances, and its ability to meet the challenges of medical advances, aging populations and rising life expectancy, depend on creative policy approaches, both to control rapidly-increasing costs and to make the most out of the resources invested.

Many observers and commentators, including at the forefront of politics, claim that problems associated with the health sector could be solved by an injection of additional funds and resources. In many countries, elected officials are under significant pressure to increase the level of resources dedicated to the health sector. However, there are indications that the overall level of resources in the health sector cannot increase significantly as they already represent a major element of public budgets, not to mention private ones. Hence, it is difficult to imagine and credibly state that the level of resources can increase, at least as a percentage of total available resources (e.g. GDP).

It is rather the overall organization of the health system that must be re-examined. Healthcare delivery is most often based on a co-management model where the interests of politicians, government officials and healthcare workers, both medical personnel professionals and other groups, highly-protected by their powerful professional and labour unions, come before those of patients and citizens.

The difficulties of health systems in our society are not due in general to an overall macro-level lack of resources invested in health services but rather to an inefficient system of production, distribution and delivery of health goods and services. A better use of resources presently dedicated to providing health services to citizens could go a long way in solving the endemic 
problems of health systems. In the health sector, as in other social and public goods and services sectors, a better use of resources means and requires a more efficient division of responsibilities between the governmental sector and the competitive sector and a systematic recourse to competitive processes and prices to guide individual choices and social investments in healthcare.

It is necessary to rebuild the system differently, going even further than the French have gone. The keywords of this important, difficult, but feasible programme are competition, modularity, experimentation, obligation of results, and performance, both in terms of effectiveness (measuring how close the outcomes and results are to the objectives) and efficiency (measuring how much resources were used to reach or deliver the results).

Responding to demands for better healthcare can increase cost pressure at a time when health spending is already climbing at a significant rate, steadily increasing the share of total resources dedicated to healthcare. Even so, spending more is not necessarily a problem, particularly if the added benefits exceed the additional costs. Since three-quarters of health spending in OECD countries is publicly financed, rising costs increase the pressure on governments to contain costs and force them to divert resources from other priorities.

Modest co-payments can relieve public-financing systems, but are no magic bullet, partly because vulnerable populations must be protected to avoid restrictions and more disparities in access that could be costly in the long run. Competitive health insurance can increase consumer choice and the responsiveness of health systems, but has not provided much help in reducing public spending, due to overwhelmingly complex interactions between the traditional public and private sectors.

The participation of non-governmental or competitive-sector organizations as healthcare providers, a standard feature of the French system, is very controversial in Canada. This controversy often derives from the fact that the term "privatization", which raises fears in some circles, is sometimes used incorrectly to describe nothing more than delegated management and multiple sourcing. Indeed, privatization can have many meanings and it corresponds sometimes to the auctioning of governmental responsibilities. In other cases, it means subcontracting certain services or functions to the competitive sector in order to increase productivity and flexibility. In 
this latter case, the governmental sector maintains ownership and responsibility for the quantity and quality of goods and services offered, even if they are contracted out to for-profit or not-forprofit competitive-sector organizations. In other cases, the term privatization is interpreted as equivalent to the increase in the financial burden of individual patients.

All these interpretations have led the debate in the wrong direction. First of all, it is important to underline the fact that there exists no health system that is entirely private or public. These expressions are mere shortcuts. For example, in the only system within OECD countries that is defined as being "private", namely the American system, public funding represents $46 \%$ of all expenditures, compared with $74 \%$ for OECD countries as a whole. If direct personal expenditures, in currency or in kind, were added to this comparison, the percentage of public spending would be (much) lower. Every health system displays varying degrees of partnerships between the public or governmental sector and the competitive sector. It is also important to keep in mind that public resources are themselves competitive: they come from citizens' competitive pocket! Therefore, it is preferable to abandon the sclerotic debate leading to a useless confrontation regarding public versus private ownership of facilities and public versus private delivery of healthcare goods and services. What is at stake is the proper understanding of the respective roles of public / governmental and competitive / non-governmental organizations and how they can be adapted as different ways and means harnessed to pursue the ultimate objective of increasing the well-being of all members of society.

Before analyzing more explicitly the role of each actor and each group of stakeholders, let us consider the financing of the health sector. Clearly, the efficient organization of the health sector is in part independent of the financing of the health system. Even with private care providers, the financing of the health system could be ensured by the governmental sector. Alternatively, part of the financing of the health system could come from the users themselves, in particular for some basic health services.

It may be efficient to ask patients to cover the costs of their use of primary care services, visits to doctors' offices, and small ambulatory surgery, as it is the case in France. The costs of such uses of health services could be income-tax deductible, fully for low-income households and partly so for higher-income ones. As in France, standard income and wealth support policies would take 
care of those households in dire financial situations, without having to design the whole health system with those households in mind.

In order to hope for such a change or at least direction of change, the (Federal) Canadian Health Act must be amended to give provincial governments the room to manoeuvre in order to implement some if not the entirety of the required programmes and processes in health care. 


\section{COMPETITIVE COMPULSORY TENDERING AND BEST VALUE IN THE UNITED KINGDOM}

\section{COMPETITIVE COMPULSORY TENDERING}

In the 80s, UK authorities introduced by law the system of Compulsory Competitive Tendering (CCT) to local governments in an attempt to improve the provision of local public services through the use of competition. Throughout the years, public services such as new construction, building maintenance, refuse collection, building cleaning, street cleaning, schools and welfare catering, grounds maintenance, repair and maintenance of vehicles, management of sports and leisure facilities, fleet management, security, architectural, engineering, property management, finance, personnel, legal, computing, corporate and administrative, housing management, hometo-school transport, libraries and theatres...were subject to competitive tendering. In particular, tender documents and service specifications of public projects and works are publicly advertised for bids. The successful bidder is awarded projects or services by a state committee. Any provider, including the local government, may contract out services. The duration of contracts ranged from three to ten years depending on statutory mechanisms tailored for each public sector.

Under the CCT, all local authorities were compelled to put out public services that they traditionally provided to their municipal population to public tender. As a consequence, works and services were performed on a contractual basis and the private sector service providers allowed into public employment. The rationale behind CCT was threefold: reduce operating costs, increase effectiveness, and improve the quality of public services. Its introduction substantially changed the management, provision, and delivery of municipal services in the UK. The impact of CCT has been reviewed extensively and while some gains were reported, unintended consequences made the following government replace the CCT with a new one called "Best Value".

CCT was first an incentive to ensure value for money in the delivery of municipal services. Many studies reported an upsurge in cost-efficiency and service improvements. Bidders pursued 
competitive performance through the setting of clearer standards and objectives, the reduction of costs and waste, and the improvement of offered services. Benefits in terms of significant savings were gained as more efficient private providers supplanted public providers and public providers become more cost-conscious and responsive. ${ }^{70} \mathrm{CCT}$ helped generate average savings of $6.5 \%$ in the first wave of tendering and $9.1 \%$ in the renewal of initial contracts. ${ }^{71}$

However, the project awarding process was much criticized. Although they were required by legislation to ensure the adequate number of bidders and notices of tenders, local authorities were able to disproportionally attribute projects to in-house municipal organizations. It was estimated that municipal departments won between $70 \%$ and $90 \%$ of tenders. ${ }^{72}$ Moreover, price has been suggested as the primary factor in winning contracts. At least $91 \%$ of all contracts were awarded to the lowest bidder during the first round of CCT and $85 \%$ during the second round. ${ }^{73}$

In response to $\mathrm{CCT}$ and to increase future prospects of contracting out projects, local authorities were to adapt their organizational management structure. As such, relationships between local authorities and their workforce were substantially changed. Local government employment at every level from blue-collar to white-collar workers were adversely impacted with new working practices such as reduced wages and employment rights. To become more competitive, local authorities had to increase productivity and trim down costs. However, as employment in public services is often subject to national pay and conditions of services, it is also less flexible in hiring and releasing staff. Several mechanisms were used to reduce labour costs. These included direct cuts in basic pay or overtime rates, reduced holidays employment, eliminated contributory benefits. A survey by UK's Department of environment concluded that one in eight jobs had been lost in services subject to $\mathrm{CCT}^{74}$

\footnotetext{
70 Frederick, D., Why compulsory competitive tendering for local government services is not as good as privatization, Libertarian Alliance, 1994.

71 Laberge, M., Comparison and competition to improve municipal services, Montreal Economic Institute, Economic Note, September 2007.

${ }^{72}$ Idem

${ }^{73}$ Pinch, P.L. and Patterson, A. "Public sector restructuring and regional development", Regional Studies, Vol. 34.3, pp. 265-275, 2000.

${ }^{74}$ Idem
}

Page | 45 
Opposition to CCT focused on its unfavourable impact on employment levels and working terms and conditions. Other reasons against CCT suggested the fact that the regime's tendering requirements had led to overly high transaction costs and mitigated against the establishment of long-term "partnership" between authorities and private contractors, as opposed to transitory market relationships. However, an Audit Commission reported that the private sector contractors were not fully motivated to enter the bidding process for various reasons including low profit margins, short duration of contracts which did not allow enough time to recoup investment, business risks such as bad publicity in case of poor performance...etc. Finally, the lack of benchmarking and the misuse of CCT provisions by local authorities (one third of private contractors made complaints against local authorities) have contributed to the repeal of CCT in January 2000.

\section{BEST VALUE}

Best Value (BV) was thus promoted by the Labour government on the grounds that it would provide local authorities with greater flexibility and freedom in how they went about reviewing services and securing improvements, and, in doing so, enable them to establish more positive (and longer term) relationships with outside providers. ${ }^{75}$ In particular, the government made clear that local authorities would not invariably need to make use of tendering processes when conducting BV reviews. Thus, in its words it "rejected the dogmatic views that services must be privatized to be of a high quality", although this rejection was accompanied by the further observation that "equally we see no reason why a service should be delivered directly if other more efficient means are available". Overall, the message from the government was therefore "what matters is what works". 76

BV is administered by the Audit Commission which carries out regular best value inspections on council services, from waste disposal to corporate strategy. A separate housing inspectorate within the commission deals with council's housing services. The performance of local authorities is measured using Best Value Performance Indicators (BVPIs) a statutory set of 90

\footnotetext{
${ }^{75}$ The DCLG Local Government Performance: http://www.bvpi.gov.uk/pages/index.asp

${ }^{76}$ DETR, Criteria for Project Selection (Department of the Environment, Transport and the Regions), 1997. 
indicators developed by Government Departments. All local authorities must measure themselves against BVPIs. The data is collected and audited annually by the Audit Commission. Each year the Department for Communities and Local Government (DCLG) works with other Government Departments to set indicators for the next year. BVPI's are set in line with the financial year (1 April to 31 March). Many of the BVPI's have been in effect since the start of $B V$ in April 2000, but some new indicators have been set, and some existing indicators were revised either to improve their definition or to be aligned with Central Government policy. Where a $B V P I$ has a target attached to it, these targets are reviewed each year, in light of the most recent performance data provide by a local council. As far as possible the Government has tried to limit the number of changes.

In addition, the Comprehensive Performance Assessment ( $C P A)$ was introduced in December 2001 as a new kind of "whole council" inspection that will rank every council in England into one of five categories, ranging from "poor" to "excellent". These rankings effectively create a league table of local government performance, with those in the premiership receiving more control over their budgets and more freedom to sell services, and those in the relegation zone being forced to accept an intensive package of government help.

The aim of BV is to ensure that within five years all council services achieve performance levels that were only achieved by the top $25 \%$ of councils at the start of the five years. The emphasis of the initiative is on continuous improvement. If a council has improved its performance from poor to average it will get a better inspection report from the Audit Commission than a council whose performance has stayed at average.

Under Best Value councils are required to apply the so-called 4 Cs to all of their services. They are: challenge, consult, compare, and compete. The Audit Commission carries out regular inspections of services to ensure that best value is being achieved. Each council is given a star rating depending on how it performs. If councils fail to demonstrate best value they could be forced to switch control of their services to other providers.

- Challenge: This involves challenging the way that councils have traditionally approached their services. Councils have to ask themselves whether they really need certain services and identify customer needs for each activity. The Audit Commission 
checks whether councils have been genuinely self-critical by checking that challenges have not just been raised, but acted upon with evidence of changes.

- Consult: Councils have to show that they have consulted local people and key local stakeholders as part of their best value reviews, and they need to monitor customer satisfaction on services. But council staff also needs to be involved in the consultation process. Again the Audit Commission checks that this consultation has been acted on.

- Compare: Under this heading councils have to benchmark their services against other councils, and private and not profit service providers. They also have to show how they are doing against national Best Value Performance Indicators, and introduce an improvement plan, however well they perform.

- Compete: This is the ominous $C$ for councils, partly because it is the aspect of best value that most resembles the old $C C T$ regime. Councils have to show that in-house services are the most cost effective by subjecting them to external competition. If inhouse services are more expensive councils may have to switch control of that activity to a private firm or the voluntary sector.

BV was enacted in April 2000 in replacement of CCT. This system is more flexible than the $\mathrm{CCT}$ as it is no longer mandatory to carry out tenders to outsource public services. However, competition remains one of the four pillars of BV. Furthermore, the control process has increased with a calibration system based on the BVPI and CPA.

The removal of CCT and its replacement by BV does not seem to have changed the way UK's local authorities decide or not to appeal to private companies: in $70 \%$ of cases studied by Higgins et al. (2005) nothing has changed. For the $30 \%$ remaining, it seems, and we can only rejoice that local authorities allow more room to private companies. ${ }^{77}$

The U.K. experience has shown that real improvements in local public services can only be achieved through a proper level of competition (with CCT or BV or some other form) among public and social goods and services providers.

\footnotetext{
${ }^{77}$ Higgins P., James P. and Roper I. (2005) "The Role of Competition in Best Value: How Far Does it Differ from CCT?” Local Government Studies, 31(2), pp. 219-235.
} 


\section{LESSONS FOR CANADA}

Canada can learn a lot from the UK experience with CCT and BV. To achieve the economies of scale underlying the performance of large cities, local municipalities must set up a system of auctions and bidding procedures that enables suppliers of municipal services, at each level and for each service, to reach the right size for them in order to achieve the bulk of economies of scale for the service in question, with the correct level of competitive pressure maintained through multiple sourcing in procurement. We know today that these goals can be met through a process of combinatorial auctions. This relatively simple solution, which in all likelihood would be broadly accepted by a large majority of citizens who wish to live together in a municipal territory that is well run for the greater well-being of all residents, is truly within our reach.

The identification, design, arbitrage and choice functions related to the baskets of municipal social and public goods and services are closely linked to and realized through the democratic electoral process. The role of the municipal competitive sector, including as in the UK under CCT the in-house municipal organizations invited to bid for municipal contracts, is to produce, distribute and deliver the municipal social and public goods and services in the most efficient manner possible using the best technologies, human resources, and organizational structures, under properly-defined incentive contracts with the municipal government.

The contracts linking the governmental-sector authorities and the competitive-sector organizations must be designed in such a way that the competitive-sector organization retained is induced to deliver on its promises through either a form of warranty bond or a significant bonus to be paid once the realization of objectives and promises has been verified. Moreover, proper pro-competitive policies must make sure that level playing field conditions are strictly enforced.

Clearly, competitive tendering may require detailed transportation contracts, whose costs would likely be small compared with their advantages. Just as you make competition play among different providers to get the best deal when you go shopping, public authorities are able to benefit from the competition in the bidding process. They can take advantage of the expertise provided by private operators - in terms of managing operating risks - and focus on service improvements. 
The experience from such reforms is certainly out there. In Europe, for example, competitive tendering is becoming the norm for municipal services including public transit, encouraged by the European Commission. France has applied this competitive model to public transit over a number of years. And other countries, such as Denmark, Sweden and Great Britain have also succeeded in reforming their municipal services and urban transit in particular with substantial operating cost reductions.

There is no reason for other large and small cities not to benefit from the same advantages of competitive tendering. Canadian municipal government could be requested to open up the provision of their services to competition through appropriate open bidding. 


\section{CHILE'S TRADE-LED GROWTH}

Chile's economic performance was dubbed "a miracle" by Milton Friedman to describe results of free-market policies between 1973 and 1983. Major reforms have followed ever since and as a result, the Chilean "miracle" has received extensive press coverage and has been invoked as a model for economic growth.

Four distinctive periods have marked Chile's history of economic reforms. Starting in 1973, the military government pursued economic stabilization with market-based policies to overcome macroeconomic imbalances such as high inflation, profound deficits...etc. In the 1980s, the financial crisis led to a series of structural reforms to boost non-traditional exports, implement active debt-reduction policies and privatize the majority of failing state-controlled firms and banks. Chile's return to democracy in 1990 did not substantially alter the applied principles of an open economy. Trade liberalization measures which included the adoption of several trade agreements, import tariff reductions, and intensive privatization efforts were continued or strengthened under the two successive democratic regimes. Until the Asian and Latin American financial crisis of the late nineties, Chile experienced a decade of sustained economic expansion with reduced macroeconomic instability. After 2000, the Chilean economy was well positioned as a small and open economy with a sound financial position to reap benefits from trade globalization, although openness made it also vulnerable to global downturns. For instance, plummeting commodity prices in 2008 hit hard the copper industry and deteriorated growth perspectives. In light of recent economic turbulences, the Chilean model might be put under further stress and test. 
Figure 4: Central Government Gross Public Debt (Percentages of GDP)

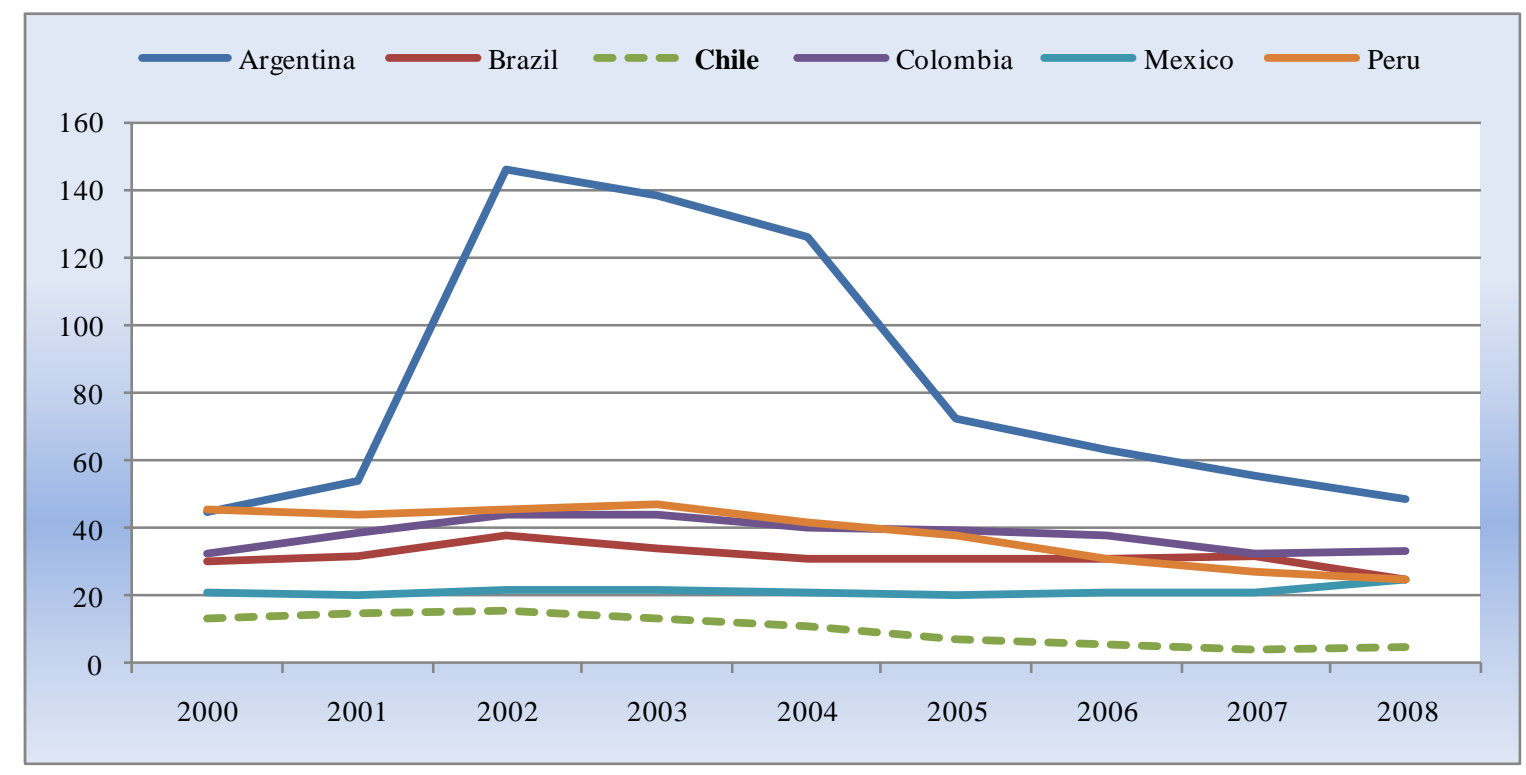

Source: United Nations, Economic Development Division of the Economic Commission for Latin America and the Caribbean (ECLAC), The Economic Survey of Latin America and the Caribbean: Policies for Creating Quality Jobs, 2008-2009 Briefing Paper.

By many macroeconomic measures, Chile has outperformed other countries in Latin America and in the developing world since the 1990s. Rapid economic growth followed years of reforms in every major sector. These structural changes included deregulation, privatization, labour and welfare legislation changes...etc. As a result, GDP per capita has more than doubled within two decades, unemployment was reduced substantially, living standards steeply improved, and the burden of public debt decreased and remained relatively low even in the years since 2000 (Figure 4).

As a small economy with a population just over 17 million Chile has chosen trade as a vehicle for economic growth. Increased competition in export-oriented and import-competing industries has eased the integration of Chile in world markets and helped establish dominant market shares in copper and fisheries. In 2008, exports reached US $\$ 67.79$ billion up substantially from US\$22.29 billion in 2000 while imports were valued at US\$57.61 billion, up considerably from US $\$ 21.42$ billion in $2000 .{ }^{78}$ Trade openness, measured as the sum of exports and imports of

\footnotetext{
${ }^{78}$ The Economist Intelligence Unit, Chile: Trade Regulations, February 2009. OECD Country Statistical Profile 2009: Chile. 
goods and service to GDP has soared from $49 \%$ of GDP in 1990 to $65 \%$ of GDP in $2007 .{ }^{79}$ Chile is believed to be reaping the benefits of earlier reforms.

Chile's better economic performance and different experience from other developing countries have been explained by the roles of major reforms. These reforms started earlier in Chile than in any other country in Latin America and that has given the country an edge over its counterparts. The first wave of changes in the 1970s was aimed at establishing macroeconomic stability in a period marked by persistent fiscal deficits and high inflation. Early measures included the privatization of state-owned enterprises (SOE) which before changes numbered 600 enterprises and nearly $40 \%$ of GDP and unifying the exchange rates by eliminating restrictions on capital. ${ }^{80}$ Initial reforms were also meant to improve resource allocation in the economy through price liberalization. By the mid-70s, tariff and non-tariff trade barriers were either eliminated or substantially reduced unilaterally. This process resulted later into the flat-rate import tariff rule for most goods. The value-added tax at a flat rate of $20 \%$ introduced in 1975 as a replacement of the sales tax constituted an important source of government revenues. ${ }^{81}$

In 1981, Chile became one of the first countries in the world to replace its pay-as-you system by a privately managed pension system. The new pension system would be run by competing private fund managers and based on individual capital accounts. Mandatory tax-deductible contributions for all workers (excluding self-employed) are deposited into savings accounts managed by the private competing funds. Workers are allowed to choose their own fund without a compulsory affiliation rule or limits on savings mobility between the competing entities. This new system contributed in raising aggregate savings and strengthening the development of Chile's capital markets.

In 2008, further reforms of the pension system emerged as competition among pension funds had diminished considerably and as many people (young workers, self-employed, contractors, and low-paid workers) had been left out of the system for diverse reasons. ${ }^{82}$ The 2008 changes

\footnotetext{
${ }^{79}$ Brieuc Monfort, Chile: Trade Performance, Trade Liberalization, and Competitiveness, IMF Working Paper 08/128, May 2008. It may be of interest to mention that the similar figures for Canada are $52.4 \%$ in 1990 and $82.9 \%$ in 2007.

${ }^{80}$ Hernandez Leonardo and Parro Fernando, "Economic Reforms, Financial Development and Growth: Lessons from the Chilean experience", Cuadernos de Economia, Vol. 45 (Mayo), pp. 59-103, 2008.

${ }^{81}$ Idem

${ }^{82}$ Including the $10 \%$ of wages obligatory minimum payment.

Page $\mid 53$
} 
aimed at including self-employed in the system (Figure 5) and increasing competition among the private pension fund managers. ${ }^{83}$

Figure 5: Chilean Workers Paying into Pension Schemes (Indices 2000=100)

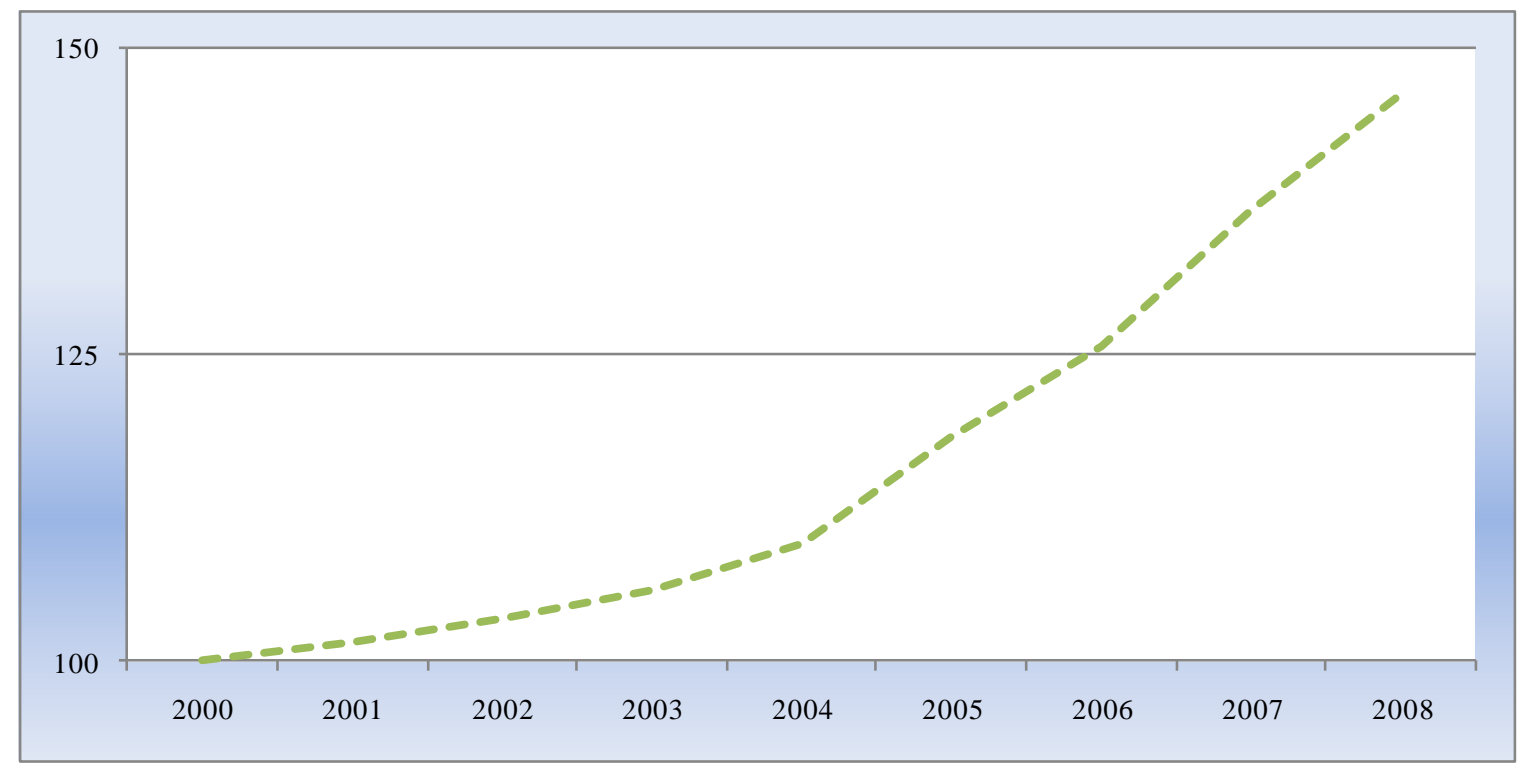

Source: United Nations, Economic Development Division of the Economic Commission for Latin America and the Caribbean (ECLAC), The Economic Survey of Latin America and the Caribbean: Policies for Creating Quality Jobs, 2008-2009 Briefing Paper.

In the financial sector, important restructuring steps were taken out to lift various restrictions. Banks were already privatized as part of the SOE reform but further changes brought the liberalization of interest rates and credit allocation so that they are controlled by the market. However, the financial liberalization that followed was not accompanied by a sound regulatory framework that could have limited moral hazard problems and their adverse effects on macroeconomic policy. Chile suffered a financial crisis in the early 1980s which has resulted on a major setback on former policies as several enterprises ended up under government control.

After the crisis, Chilean authorities started an era of institutional reforms. Regulatory and supervisory bodies were given more powers to monitor many sectors. The banking system was forced to keep pace with international standards and best practices. Monopolies were dismantled

${ }^{83}$ Chilean Ministry of Finance: http://www.hacienda.gov.cl/english/informacion_inversionista/why chile.php 
and many SOEs were privatized again. The central bank's monetary policies evolved towards less intervention on the exchange rate market and stable inflation rate targets. Taxation policies were also renewed to include stronger incentives for savings and investments. For instance, the corporate tax rate was reduced; tax credits were given to shareholders to avoid double taxation on dividends, and to investors spending on initial public offerings. ${ }^{84}$ By the late 1990s, the private sector was allowed to operate in infrastructure development projects (roads, airports, etc.) and the telecommunications sector.

Chilean authorities brought a major turnaround in trade policy in the 1970s. They adopted a freetrade strategy tearing down barriers and quota systems and creating one of the world most liberal and transparent trade regime. Over the years, policies liberalizing trade restrictions were implemented, the most important of which being the adoption of a uniform import-tariff policy. In 2003, the flat-rate import tariff was reduced to a low of $6 \%$ from $7 \%$ in 2002 and $10 \%$ in 1999, as a continuation of trade liberalization. ${ }^{85}$ In addition, Chile entered into multiple trade agreements with different trading partners since 1991. Schedules of tariff reductions are embedded in some free-trade agreements and as a result, Chile's trade-weighted average effective import tariff rate has been estimated at $1.4 \%$ in $2008 .{ }^{86}$ In many cases, these agreements provided accords on competition issues, government procurement, dispute-settlement procedure, and more that led to significant improvement in Chile terms of trade in goods (Figure 6).

\footnotetext{
${ }^{84}$ Hernandez Leonardo and Parro Fernando, "Economic Reforms, Financial Development and Growth: Lessons from the Chilean experience", Cuadernos de Economia, Vol. 45 (Mayo), pp. 59-103, 2008.

${ }^{85}$ Idem

${ }^{86}$ Idem

Page $\mid 55$
} 
Figure 6: Terms of Trade for Goods (Indices 2000=100)

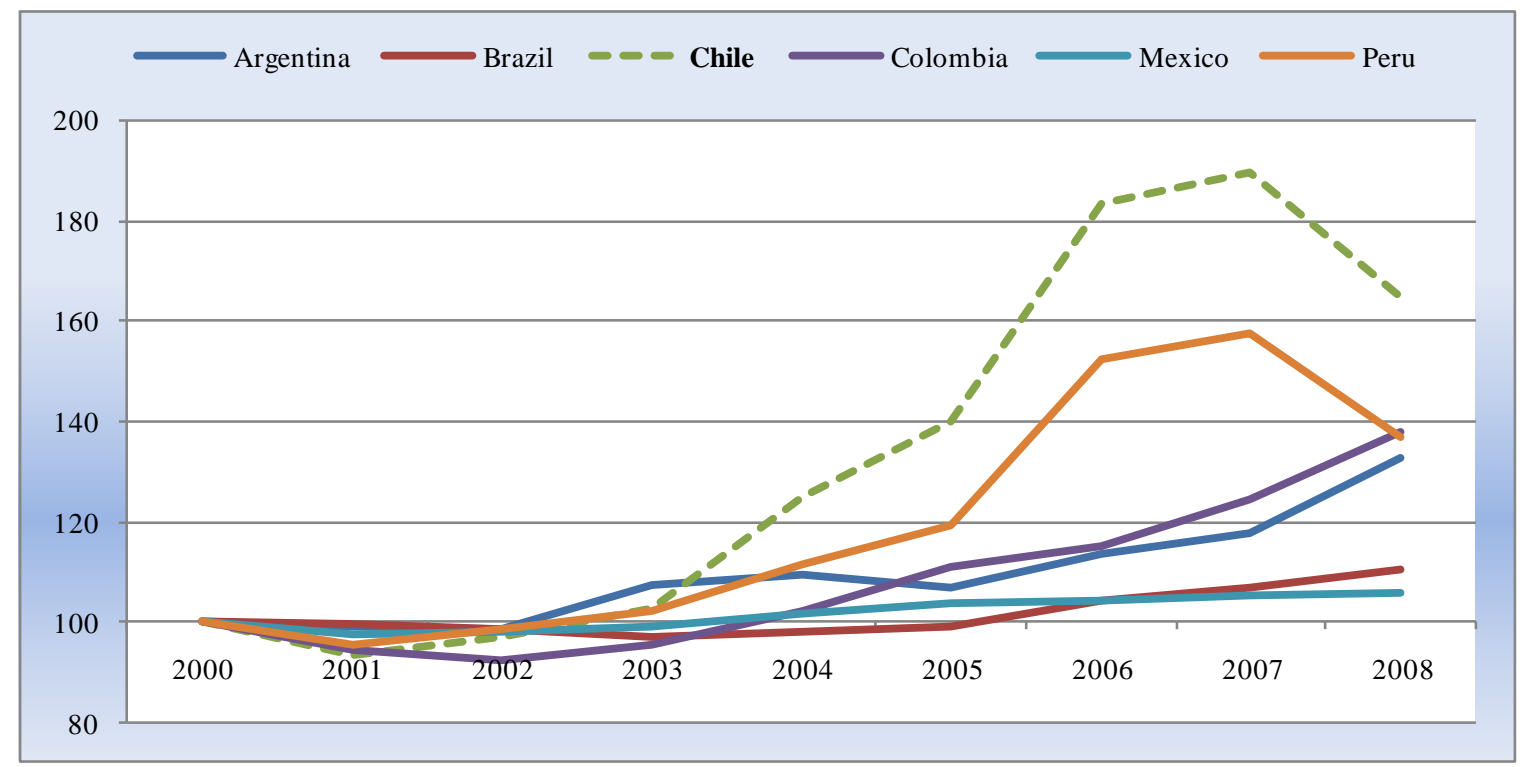

Source: United Nations, Economic Development Division of the Economic Commission for Latin America and the Caribbean (ECLAC), The Economic Survey of Latin America and the Caribbean: Policies for Creating Quality Jobs, 2008-2009 Briefing Paper.

A value-added tax on cost, insurance and freight of $19 \%$ is applied to all imports. ${ }^{87}$ Few products (sugar, wheat, and oilseeds) are subject to special regimes. In fact, Chile's most important nontariff barrier has been the use of an import-price band system as a means to realign the prices of certain agricultural products. As a result, additional duties or rebates have been imposed respectively to products for which the reference price is either lower or higher than the thresholds of a price band.

At the same time and in the same vein, significant price liberalization and competition enhancing policies were enacted. Those policies made the Chilean economy much more efficient in reallocating resources to more beneficial activities.

According to the OECD, agriculture's share of employment was estimated at 12\% in 2006 down from $19 \%$ in 1990 and the sector now accounts for just below 4\% of GDP. ${ }^{88}$ Despite its relatively

\footnotetext{
${ }^{87}$ There are two generally accepted methods for calculating duty rates: CIF (Cost, Insurance, and Freight) and FOB (Free on Board). Most countries use the CIF method. Some exceptions may apply. VAT (Value Added Taxes) are generally applied on the CIF or FOB + Duty value. Duty is calculated by adding all costs together. The CIF is a pricing term indicating that the cost of goods, insurance, and freight are included in the quoted price.

${ }^{88}$ Organization for Economic Co-operation and Development, OECD Review of Agricultural Policies: Chile, 2008.
} 
low share of GDP, the agricultural sector has been very important to Chile's economic success. The sector has also benefited from liberalization and trade-oriented reforms and has been progressively leaning towards exportable commodities. The OECD reports that the share of primary agricultural trade (i.e. exports plus imports) in agricultural GDP averaged 30\% during the period of military government (between 1973 and 1990), reached 60\% between 1990 and 1998, and has averaged more than $80 \%$ since $1999 .{ }^{89}$ At the same time, Chile has diversified its agribusiness exports to encompass more than the dominant wine and fruits sectors with poultry and dairy products. Between 2004 and 2006, the producer support as a share of gross farm receipts averaged only $5 \%$ compared to $30 \%$ in other OECD countries. In addition, total support to the agricultural sector accounted for $0.4 \%$ of GDP, in comparison with an average of $1.2 \%$ in OECD countries, between 2003 and 2005. Agricultural policies in Chile are well characterized by low support to producers and the organization of small-scale farmers into viable commercial structures.

On another front, Chile's government created two sovereign wealth funds (SWF) in 2006 reflecting years of strong economic growth. A SWF is an investment fund owned by a government and usually originates from "excess" funds accumulated through trade of a natural resource or savings in foreign exchange reserves. Following windfall earnings from its copper export industry, Chilean authorities set up the Economic and Social Stabilization Fund (ESSF), which is to provide funding for public education, health, and housing initiatives, and the Pension Reserve Fund (PRF), which is to provide funding for the government's pension obligations. ${ }^{90}$ Unlike other countries, Chile has tied the growth of its SWF to budget surpluses in order to accumulate more than extra copper revenues. The SWF operations are managed by the Chilean central bank with the supervision of the Finance Ministry and an advisory committee.

\footnotetext{
${ }^{89}$ Organization for Economic Co-operation and Development, Agricultural Policy Reform in Chile, March 2008.

${ }^{90}$ Kristian Flyvholm, Assessing Chile's Reserve Management, IMF Monetary and Capital Markets Department, November 6, 2007. 
As of July 2009, the ESSF market value was estimated at US\$ 15.0 billion while that of the PRF reached US\$ 3.4 billion according to the Chilean ministry of Finance. The Chilean SWFs are considered as passive investment funds as they have not been directly invested in companies. In fact, authorities have followed a simple investment strategy outlined as $66.5 \%$ in sovereign bonds, $30 \%$ in money market instruments, and 3.5\% in inflation-indexed sovereign bonds. In addition, the currency composition of the funds is broken down as follows: $50 \%$ USD, $40 \%$ Euro, and $10 \%$ Japanese Yen. ${ }^{91}$

These funds' importance has grown in time and more importantly in face of current global downturn. Not only countries with SWFs have been able to better cushion the economic downturn effects but they also provided capital infusion into ailing financial institutions in the western world.

\section{Figure 7: Domestic Credit to the Private Sector (End-of-year balances as percentages of} GDP)

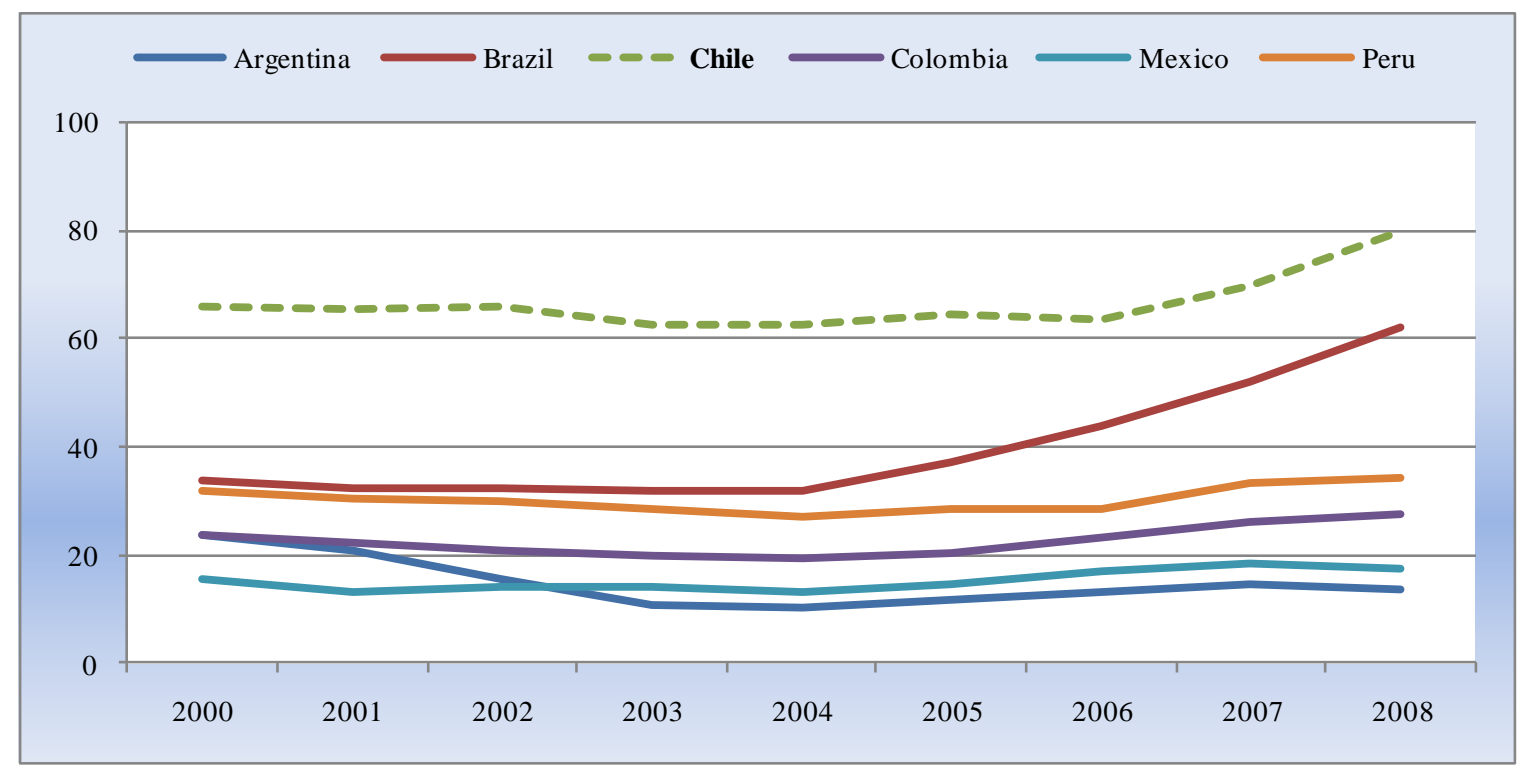

Source: United Nations, Economic Development Division of the Economic Commission for Latin America and the Caribbean (ECLAC), The Economic Survey of Latin America and the Caribbean: Policies for Creating Quality Jobs, 2008-2009 Briefing Paper.

There has been a continuous effort to improve policies in Chile. In fact, economic policy programs towards liberalization are being deepened and the fostering of competition in major

${ }^{91}$ Chilean Ministry of Finance: http://www.hacienda.gov.cl/english/fondos_soberanos/index.php 
sectors particularly that of import and export industries is further pursued. More importantly, the sounder institutional framework has helped sustain policies towards competitive pricing throughout the economy. Fernando and Parro (2008) report that by having institutions of quality similar to Chile's, the average Latin American country could raise its per-capita GDP growth rate by about $1.5 \%$ on average. Many studies agree that continuous developments such as structural and institutional reforms, trade openness as well as market and price liberalization have resulted in large pay-offs of economic growth.

\section{LESSONS FOR CANADA}

Canada has a significantly open economy. But Canada suffers from manipulated prices even if many institutions are involved in the protection of competitive mechanisms by making sure that markets function efficiently. The primary obstacle faced by such institutions is in conceiving the proper framework that includes corrective measures when the pricing behaviour of participating organizations may, in reality, destroy or reduce competition.

This difficult task proves even more complex when a government wishes to manipulate prices not for economic performance concerns, but in order to protect or favour some groups considered deserving, particularly vulnerable, or of a particular interest with regard to some social aspects. Such a policy of manipulating prices is not an adequate solution and should be strongly opposed to in favour of more adequate policies.

Competitive prices are signals on relative scarcity of goods and services, in particular of public and social goods and services, on which individuals and organizations can plan not only their consumption and purchases but also their production efforts and investments. Unless such information is available and transparent, it is difficult for the general public to ascertain the value of investments and efforts to provide more value for the citizens. Innovation and creativity rest on the provision of information on relative scarcity to the different stakeholders in the production and distribution of public and social goods and services.

In the case of energy prices, for example, the result is always a poorly-oriented resource development policy that, based on price manipulation, benefits mainly the groups directly 
involved, while squandering the potential gains from a socially-optimal resource exploitation plan. This is a policy that will inevitably and inexorably lead to collective impoverishment. The policy of low energy prices always ends up being financed by higher public debt and taxes, leading to a deterioration of social services, as well as infrastructures thereby impairing future economic development. It is not only an inefficient subsidy to big energy consumers, including both individuals and corporations, but also a regressive transfer from poor to rich.

Commentators often hail the relatively low (manipulated) level of energy prices for helping achieve a high level of economic development. What that hides, however, is the real social cost of the policy. The real price of energy remains its opportunity cost, which could be significantly higher because it equals the maximum competitive price at which energy can be sold. The traditional response of special interest groups who gain from this policy is that everybody benefits from low prices. Nothing could be further from the truth. Distortions in price signals destroy potential wealth and in so doing hurt a majority of citizens, especially the poor.

The case of agricultural support is even more troubling. In most contemporary social democracies, agriculture and agribusiness are heavily subsidized sectors, most often to the detriment of better food at lower prices for all citizens. The situation is due to well-organized interest groups whose political influence peddling is abnormally high. The channels through which political support is provided differ across regions and countries: direct financial subsidies, supply management or production quota systems, price floors, import restrictions (tariffs and/or quotas), etc. In all cases, the effect is similar: lower-quality product, less diversity, higher prices. If farmers and breeders were in need of special support for reasons that are absent from other industries facing economic difficulties and changing social and economic environment, then it would be better to explicitly determine the level of support and grant it directly in an incentivecompatible way without manipulating the price system. This way, the social cost of such support would be minimized while assuring its social benefits if any.

Similar analysis could be performed for education and health, which are sectors where the manipulation of prices creates socially costly distortions in the allocation of resources, to the advantage of special interest groups and to the detriment of social well-being. Such distortions benefit the rich and wealthy much more than they benefit the poor and needy. On this basis 
alone, they should, in fact, be opposed in favour of more efficient and equitable direct income and wealth support for the poor and the needy, perhaps through the anonymity of the income tax system. 


\section{CONCLUSION: Four worthy studies to undertake}

In characterizing the role, scale and scope of the State in different national social and economic systems, it is useful to analyze its three fundamental missions, namely (i) provider of last resort, (ii) planner of design activities and programmes, (iii) regulator and guarantor of the legal framework and integrity of markets as an exchange mechanism. Moreover, in undertaking these missions, actions and interventions of the State must be analyzed in conjunction with the ways and means used.

WE first characterized the general features of national social and economic systems, presented in a typology with four different broad systems. We insisted on two aspects: there are important differences between national social and economic systems and it is important to distinguish between the objectives pursued and the ways and means used to meet the challenges raised by the role, scale and scope of the State.

WE then showed, in reference to specific government policies (in Sweden, France, and the UK), how the analysis of ways and means used to implement these policies provides new information and better understanding of social and economic systems. These analyses led to lessons for Canada. Finally, we considered the case of Chile, which is a source of other important lessons for Canada.

It is important to realize that Canada has been very successful in a broad sense, especially since the mid-nineties, following the general consensus at the federal level as well as the provincial level on the necessity to eliminate government deficits. The Canadian performance ranks in general among the very best developed countries, although there is certainly room for improvement in some specific aspects.

From our discussion of the four broadly defined national economic models (Nordic, AngloSaxon, Continental, Mediterranean), the specific government policies (education in Sweden, health provision in France, compulsory competitive tendering in the UK, and the price liberalization movement in Chile) and the identification in each case of lessons for Canada, there are four important research studies or programmes worth undertaking for Canada. Although each 
subsection "Lessons for Canada" describes potential research programmes on topics of importance the following four programmes clearly constitute a significant addition to such research agenda.

IPM: An index of price manipulation (non competitive prices)

It would be interesting to launch a research programme into the manipulation of prices in Canada and other countries, that is, into the policy-based creation of wedges between observed prices and what would be perfectly competitive prices. Such a suggestion is inspired by the Chilean policy compact of the last 35 years.

There is a strong consensus among economists that the main factors explaining differences in performance between countries and regions in terms of economic growth, welfare and living standards are the following: the quantity and quality of human capital, the ability to invent and innovate, the quality and intensity of incentive mechanisms and, ultimately, the quality of mechanisms for allocating private and public resources and coordinating decisions.

Growth, productivity and welfare depend mainly on rules of governance in organizations and institutions, namely the incentive mechanisms and mechanisms for resource allocation and decision coordination. Certainly, skills and human capital, inventions and innovations, as well as natural resources are key determinants of growth and well-being, but the good governance of public and private affairs is probably the most important factor. This is because the rules of good governance will shape the development, evolution and adaptation of skills and human capital, the choice of investments and therefore the portfolio of technologies, as well as how natural resources are exploited for the benefit of all.

Competitive mechanisms and prices are efficient coordination and motivation mechanisms for citizens and organizations as they allow the expression of choices based on appropriate information. Price manipulations, however well intentioned, can be major sources of economic and social waste in our societies because manipulated prices send to citizens and businesses biased signals or indicators of relative costs and relative scarcity of goods and services. 
These manipulations lead people to make poor decisions regarding consumption and investment. They also lead businesses and organizations, including those of the public sector, pertaining to health and education for example, to choose wrong levels of output, investment and R\&D. Faced with appropriate indicators (competitive prices and mechanisms), individuals and businesses can adapt their decisions on consumption and production, including investments in human capital (skills portfolio), $\mathrm{R} \& \mathrm{D}$ and innovation, on the relative social value of these activities, as revealed by competitive prices. In some cases, fostering effective and knowledgeable decisions require the creation and development of competitive markets in lieu of traditional bureaucratic decision making.

Insofar as the performance and competitiveness of an economy depends largely on the quality of its mechanisms of coordination and motivation, the competition index, if constructed in a rigorous, transparent and credible way, could enable economies and societies to take concrete steps based on best practices and competitive pricing mechanisms, to improve their performance, competitiveness and well-being of their citizens. Such index could also quickly reach a high level of international recognition.

The research programme proposed would aim at the conception and implementation of a methodology to compute an index of non competitive prices (IPM) in Canada and other countries. Presumably, this index could be used as a measure of how well or poorly the resource allocation mechanisms work in a given country in comparison with other countries. One may expect that such an index, published annually for many countries, would generate sufficient public exposure to influence relevant government policies.

\section{A revision of the Canadian Health Act to favour more flexibility and modularity}

A second research programme should be launched to ascertain the ways and means of generating more flexibility and modularity in the Canadian health care system to control growing costs while improving quality.

The federal government's role in healthcare includes, among other responsibilities, setting and administering national principles for the system under the Canada Health Act and providing 
financial support to the provinces through Canada Health Transfer. It includes also important responsibilities for health protection, food safety and nutrition, and regulation of pharmaceuticals, medical devices, and consumer health products.

The Canada Health Act establishes the principles and criteria for health insurance plans that the provinces and territories must meet in order to receive full federal cash transfers in support of health programmes. The Canada Health Act lists five basic principles, which state that health care plans must be available to all eligible residents of Canada, comprehensive in coverage, accessible without financial and other barriers, portable within the country and during travel abroad and publicly administered.

The (Federal) Canadian Health Act must probably be amended (as well as the rules of the transfer payments to provinces) to give provincial governments room to manoeuvre in order to implement policies intended to inject more flexibility and modularity in their health systems. The stumbling block seems to be the requirement that health care plans must be publicly administered: "The provincial and territorial plans must be administered and operated on a nonprofit basis by a public authority accountable to the provincial or territorial government." This requirement seems to imply that private care providers must essentially be left out of the public system.

As presented above, the French Health System, which satisfies the five (at least the first four) principles of the Canada Health Act, leaves a very significant place to private providers, which are both profit seeking (listed on stock exchanges) and fully integrated to the public system. This creates a form of competition within the public health system and has produced interesting results, both in terms of the management of the system and in terms of the level and quality of care provided to citizens.

It might be interesting to include in the research programme projects characterizing the way to introduce private providers of care into the public health care system. Different provinces could possibly (or might be allowed to) opt for different public-private packages under the new Canadian Health Act. The objective of the project would be to ascertain what changes in the Act are deemed necessary to provide the proper level of competition as a means to control growing costs while improving the quality of Canadian health care. 


\section{A more efficient employment security approach}

It would be interesting to launch a research programme on the factors allowing a high level of employment security and a high level of labour market flexibility. Too often, public interventions have been earmarked to protect jobs rather than employment and employability. As mentioned above, there are different dimensions of labour market security. An interesting concept is that of flexisecurity. It is a way to foster labour market security while maintaining a sufficiently-mobile labour force. The Swedish model of employment security is very often regarded as simultaneously efficient and equitable.

Let us recall that flexisecurity is defined as a mechanism for enhancing the flexibility of labour markets, work organization and labour relations and for enhancing security - employment security and social security - notably for weaker groups. There exist many variations of flexisecurity depending on the weight which is allotted to each of the two elements that make up this policy strategy.

The pursuit of generic policies and programmes fostering employability requires a fair dose of modularity and experimentation to identify best practices. No centralized system of bureaucratic commands and controls can achieve such objectives. The main reason for that is by now well known: the quantity of information to be collected, handled and processed is so huge that any centralized system is bound to fail. The research programme could identify winning conditions. They are likely to be quite different from the system we now have in place in Canada. But how different could it be?

It bears repeating that the links between the creation, sharing and redistribution of wealth are complex but need not be in conflict, provided that certain determining factors are well understood. We must find a way to integrate objectives of efficiency, effectiveness, and social cohesion and, in so doing we must better understand the ways and means of wealth creation and redistribution.

There probably exists a level of inequality in the sharing of income or wealth that enhances the well-being of everyone. There are two reasons for this. First, incentives for creativity, innovation and entrepreneurship are a fundamental and essential factor in economic development. Second, 
for the results of this creation and innovation to be fruitfully applied and commercialized, highlytrained and highly-skilled human resources are required. At a time of accelerated wealth creation and increased uncertainty such as over the last quarter century, the pressures on these resources push up their value compared to that of basic human resources with lower levels of skills and competencies in putting those new production technologies and organizational forms to work. This provides a powerful incentive to acquire such skills. This phenomenon strongly suggests that wealth can be redistributed in an effective and sustainable way only through the adaptation of the portfolio of skills possessed by individuals, thereby raising their market value, that is, their value to fellow citizens.

By establishing institutions and mechanisms promoting this continuous, rapid and orderly adaptation of skill portfolios, governments can best foster a proper connection between wealth creation and redistribution. The best way to redistribute wealth in a durable way is to promote the participation of each and everyone in its creation.

It therefore might be interesting to launch a research programme into a more incentive-based employment protection system, which provides both protection through employability and incentives to acquire the skills that are in strong demand. It is a complex equation and balance to achieve, but a sure way, if successful, to increase both economic growth potential and social well being for Canada.

\section{A comparative analysis of cross country performance (GDP growth and job creation)}

As mentioned above, Canada has had a favourable economic performance over the last quarter century, especially since the mid-nineties, following the general consensus at the federal level as well as the provincial level on the necessity to eliminate government deficits. Between 1981 and 2007, employment has increased by 50\%, nominal GDP (expressed in US\$ at PPP prices) by $312 \%$ and the level of nominal GDP per person employed increased from $27,539 \$$ to $75,719 \$$, an increase of $175 \%$. The table below presents those statistics for nine other developed countries, indicating that Canada is third in terms of employment growth behind Australia and the Netherlands; fifth in terms of nominal GDP (in US\$ at PPP) growth behind Australia, the US, the 
Netherlands, and the UK; and ninth, only ahead of Germany, in terms of the growth of GDP per person employed.

Table 1

Nominal GDP growth (US\$ at PPP prices), Employment growth, Nominal GDP/employment

\begin{tabular}{lccccc} 
& $\begin{array}{c}\text { GDP Growth } \\
\text { (1981-2007) }\end{array}$ & $\begin{array}{c}\text { Employment Growth } \\
(\mathbf{1 9 8 1 - 2 0 0 7})\end{array}$ & \multicolumn{3}{c}{ GDP/Employment } \\
\cline { 2 - 6 } Australia & $359 \%$ & $64 \%$ & 1981 & 2007 & $2007 / 1981$ \\
Canada & $312 \%$ & $50 \%$ & 27,539 & 75,719 & $175 \%$ \\
France & $258 \%$ & $18 \%$ & 27,190 & 82,822 & $205 \%$ \\
Germany & $263 \%$ & $10 \%$ & 29,491 & 74,814 & $154 \%$ \\
Italy & $215 \%$ & $13 \%$ & 28,384 & 78,995 & $178 \%$ \\
Japan & $265 \%$ & $15 \%$ & 21,387 & 67,603 & $216 \%$ \\
Netherlands & $325 \%$ & $51 \%$ & 27,232 & 76,401 & $181 \%$ \\
Sweden & $248 \%$ & $7 \%$ & 22,836 & 73,976 & $224 \%$ \\
United Kingdom & $324 \%$ & $20 \%$ & 21,090 & 74,435 & $253 \%$ \\
United States & $343 \%$ & $45 \%$ & 30,931 & 94,090 & $204 \%$ \\
\cline { 2 - 5 } & & & & &
\end{tabular}

\section{Sources}

[1] OECD Data 2009

[2] Bureau of Labor Statistics. "International Comparisons of Annual Labor Force Statistics, Adjusted to U.S. Concepts, 10 Countries, 1970-2008". Retrieved on November $17^{\text {th }} 2009$.

One can observe that there are significant differences between the experiences of different countries. It would be interesting to launch a research programme into identifying the factors underlying the comparative performance of these countries and others. Clearly, these differences are not the result of random factors.

It is tantalizing to suggest that there are links between those relative performances and the macroeconomic models discussed briefly above, namely the Nordic model, the Anglo-Saxon Page $\mid 68$ 
model, the Continental model, and the Mediterranean model. However, some countries, belonging in general to the same economic model, have experienced very different growth paths as their resources and challenges differed during the studied period.

The data in the above table end on purpose in 2007, that is, before the recession encountered worldwide following the "subprime" financial crisis. It would be interesting to relate these performances to how differently economies behaved during the recent financial crisis and economic recession. How can one characterize and explain the relative resilience of certain economies and what implications can one derive for future public policies? 


\section{REFERENCES}

1. Aiginger, Karl, The Swedish Economic Model, WIFO Working Papers, No. 302, October 2007.

2. Albrecht, J., van den Berg, G. and Vroman, S., The Aggregate Labour Market Effects of the Swedish Knowledge Lift Program, Centre for Economic Policy Research CEPR Discussion Paper No. 5927, 2006.

3. Autorité de Régulation des Communications Électroniques et des Postes (ARCEP). Information available at : www.arcep.fr.

4. Boeri, T., 'Let Social Policy Models Compete and Europe Will Win', Paper presented at a conference hosted by the Kennedy School of Government, Harvard University, 11-12 April 2002.

5. Böhlmark, A. and Lindahl, M., Does School Privatization Improve Educational Achievement? Evidence from Sweden's Voucher Reform, The Institute for the Study of Labour (IZA), Discussion Paper No. 3691, September 2008.

6. Boyer M. and Robert, J., "Competition and Access in Electricity Markets: ECPR, Global Price Cap and Auctions," pp. 47-74 in Georges Zaccour (ed.), Deregulation of Electric Utilities, Kluwer Academic Pub., 1998.

7. Boyer, M., «La performance et le développement économiques du Québec: les 12 travaux d'Hercule », CIRANO, novembre 2009.

8. Boyer, M., "Le secteur privé dans un système de santé public: France et pays nordiques », CIRANO, Février 2008.

9. Boyer, M., « Manifesto for a Competitive Social Democracy », CIRANO Monograph 2009.

10. Boyer, M., «The Economic Crisis and Employment Dynamics: The Creative Destruction at Work », Montreal Economic Institute, November 2009.

11. Boyer, M., Benitah, M. and Sun, W., "Real Options, Network Development and Network Access", WIK NETCONOMICA 2008 Conference on "Current Issues in Network Economics: Regulatory Risk, Cost of Capital and Investment Incentives," September 2008, Königswinter, Germany.

12. Boyer, M., Christofferson, P., Lasserre, P. and Pavlov A., "Value Creation, Risk Management and Real Options," Icfaian Journal Of Management Research, October 2004 (CIRANO 2003RB-02).

13. Buckley, J. and Schneider, M., "Are Charter School Parents More Satisfied With Schools? Evidence from Washington, DC," Peabody Journal of Education 87(1), 57-78.

14. Caldwell, B.J., School-based Management, International Institute for Education Planning, UNESCO, Paris, p. 1, 2005.

15. Chaney, R., President Obama's Education Vision Falls Short, Pacific Research Institute, April 2009.

16. Chilean Ministry of Finance: http://www.hacienda.gov.cl/english/fondos soberanos/index.php 
17. Chilean Ministry of Finance:

http://www.hacienda.gov.cl/english/informacion inversionista/why chile.php

18. Conseil de la concurrence, Décision no. 05-D-65 du 30 novembre 2005 relative à des pratiques constatées dans le secteur de la téléphonie mobile. Disponible à : $\underline{w w w . a r c e p . f r}$

19. Davis, S. and Henrekson, M., Economic Performance and Work Activity in Sweden after the Crisis of the Early 1990s, NBER Working Paper No. 12768, December 2006.

20. European Commission, Health and Long-term Care in the European Union, Special Eurobarometer 283, December 2007.

21. Flyvholm, K., Assessing Chile's Reserve Management, IMF Monetary and Capital Markets Department, November 6, 2007.

22. Frederick, D., Why compulsory competitive tendering for local government services is not as good as privatization, Libertarian Alliance, 1994.

23. French Ministry of Health, Youth and Sports, Les établissements de santé : un panorama pour l'année 2005, 2007.

24. French Ministry of Health, Youth and Sports, Les établissements de santé: un panorama pour l'année 2006, 2009.

25. Frontier Centre for Public Policy, Sweden's School Voucher Program Choice and competition improve all schools, public and private, May 2005.

26. Fuller, T. and Ekman, I., The Envy of Europe, The New York Times, September 2005.

27. Gomes, A. et al. "Sickness, Disability and Work: Breaking the Barriers, Sweden: Will the Recent Reforms Make it?” OECD 2009.

28. Government of Alberta: http://www.learning.gov.ab.ca/educationsystem/charter_hndbk.pdf

29. Guger, A., Leoni, T. and Walterskirchen, E., European Socio-Economic Models: Experiences and Reform Perspectives, Annex 3 - EUROFRAME-EFN Autumn 2007 Report.

30. Haucap, J., Buehler, S. and Dewenter, R., "Mobile Number Portability in Europe" (July 2005). Available at SSRN: http://ssrn.com/abstract=765224

31. Hausman, J. and Myers, S., "Regulating the United States Railroads: The Effects of Sunk Costs and Asymmetric Risk," Journal of Regulatory Economics 22(3), 287-310, 2002.

32. Hepburn, C. and Merryfield, J., School Choice in Sweden - Lessons for Canada, Fraser Institute Occasional Paper, November 2006.

33. Hernandez, L. and Parro, F., "Economic Reforms, Financial Development and Growth: Lessons from the Chilean experience", Cuadernos de Economia, Vol. 45 (Mayo), pp. 59-103, 2008.

34. Higgins, P., James, P. and Roper, I. (2005) "The Role of Competition in Best Value: How Far Does it Differ from CCT?" Local Government Studies, 31(2), pp. 219-235. 
35. Kaiser Family Foundation, Cost Sharing for Health Care: France, Germany, and Switzerland, January 2009.

36. Krantz, O., Economic Growth and Economic Policy in Sweden in the 20th Century: A Comparative Perspective, The Ratio Institute, March 19, 2004.

37. Laberge, M., Comparison and competition to improve municipal services, Montreal Economic Institute, Economic Note, September 2007.

38. Labrie, Y., How to Explain the Success of the Swedish Model, Montreal Economic Institute, Economic Note - July 2007.

39. Labrie, Y, and Boyer, M., The Private Sector within a Public Health Care System: The French Example, Montreal Economic Institute, Health Care Series, April 2008.

40. Maddison, A., The World Economy: Historical Statistics, OECD, 2003.

41. McKinsey Global Institute, Sweden's Economic Performance: Recent Development, Current Priorities, May 2006. Available at http://www.mckinsey.com/mgi/publications/sweden

42. Monfort, B., Chile: Trade Performance, Trade Liberalization, and Competitiveness, IMF Working Paper 08/128, May 2008.

43. National Center for Health Statistics, Health, United States, 2007: With Chart book on Trends in the Health of Americans, U.S. Department of Health and Human Services, 2007, p. 364.

44. New York Times Video Op-ed available at: http://video.nytimes.com/video/2009/03/15/opinion/1194838660912/op-ed-sweden-s-choice.html

45. Nolte, E. and McKee, M., "Measuring the health of nations: updating an earlier analysis", Health Affairs, Vol. 27 (2008), No. 1, pp. 58-71.

46. Nordic Council of Ministers, "Growth in the Nordic business sector", Copenhagen 2007, available at: http://www.norden.org/sv/publikationer/publikationer/2008-503/at_download/publicationfile

47. OECD Employment Outlook, 2004.

48. OECD Health Data 2009.

49. OECD Observer (September 2004).

50. OECD Press Release, Sweden's sickness and disability reforms on track but could be improved, says OECD, March $3^{\text {rd }} 2009$.

51. OECD, Agricultural Policy Reform in Chile, March 2008.

52. OECD, Knowledge and Skills for Life: First Results from PISA 2000, Programme for International Student Assessment, 2001, p 178, http://www.oecd.org/dataoecd/44/53/33691596.pdf.

53. OECD, Learning for Tomorrow's World: First Results from PISA 2003, Programme for International Student Assessment, 2004, p. 236, http://www.oecd.org/dataoecd/1/60/34002216.pdf.

54. OECD, OECD Review of Agricultural Policies: Chile, 2008. 
55. OECD, OECD's Education at a Glance: OECD Indicators 2005, OECD 2005.

56. OECD, Reviews of Regulatory Reform, Regulatory Reform in France. Regulatory Reform in the Telecommunications Sector, OECD 2003.

57. OECD, Tax and Growth: What Direction should Sweden Take? Lecture by Angel Gurría, OECD Secretary-General, at Stockholm School of Economics, Stockholm, 22 April 2008.

58. Pinch, P.L. and Patterson, A. "Public sector restructuring and regional development", Regional Studies, Vol. 34.3, pp. 265-275, 2000.

59. Sapir, A., 'Globalization and the Reform of European Social Models', Journal of Common Market Studies, Vol. 44, No. 2, pp. 369-390, June 2006.

60. Sianesi, B., Swedish active labour market programmes in the 1990s: Overall effectiveness and differential performance, The Institute for Fiscal Studies, February 2002.

61. Swedish Ministry of Education and Research, Funding of the Swedish school system, March 2008.

62. The Canadian Encyclopaedia. Information available at: http://www.thecanadianencyclopedia.com/index.cfm?PgNm=TCE\&Params=A1ARTA0010090

63. The DCLG Local Government Performance: http://www.bvpi.gov.uk/pages/index.asp

64. The Economist Intelligence Unit, Chile: Trade Regulations, February 2009. OECD Country Statistical Profile 2009: Chile.

65. The Economist, "Vive la difference", May $7^{\text {th }} 2009$.

66. The Economist, A Decade in the Sun, June $5^{\text {th }} 2008$.

67. The Economist, A New Pecking Order, May $7^{\text {th }} 2009$.

68. The Economist, The Swedish Model, September $7^{\text {th }} 2006$.

69. Trends in International Mathematics and Science Study, information available at: http://timssandpirls.bc.edu/TIMSS2007/mathreport.html

70. UK Department of the Environment, Transport and the Regions (DETR), Criteria for Project Selection, 1997.

71. United Nations, Economic Development Division of the Economic Commission for Latin America and the Caribbean (ECLAC), The Economic Survey of Latin America and the Caribbean: Policies for Creating Quality Jobs, 2008-2009 Briefing Paper.

72. US Bureau of Labor Statistics, "International Comparisons of Annual Labor Force Statistics, Adjusted to US Concepts, 10 Countries, 1970-2008", Retrieved on November $17^{\text {th }} 2009$ at www.bls.com

73. Wilthagen, T., (2002), "Managing Social Risks with Transitional Labour Markets", in Mosley, H., J. O'Reilly and K. Schönmann, eds., Labour Markets, Gender and Institutional Change, Cheltenham: Edward Elgar.

74. World Health Organization, information available at www.who.org. 